\title{
ANÁLISE ESTRATIGRÁFICA DO GRUPO SANTA BÁRBARA (EDIACARANO) NA SUB-BACIA CAMAQUÃ ORIENTAL, RS
}

\author{
GELSON LUÍS FAMBRINI ${ }^{1} \&$ ANTONIO ROMALINO S. FRAGOSO-CESAR ${ }^{2}$
}

\begin{abstract}
Resumo O Grupo Santa Bárbara (Ediacarano) apresenta cerca de $6000 \mathrm{~m}$ de espessura na Sub-Bacia Camaquã Oriental. O grupo é representado por sucessões de arenitos e ritmitos marinhos a costeiros, e de conglomerados e arenitos aluviais, dispostos em ciclos progradacionais e retrogradacionais. Estudos estratigráficos de fácies, paleoambientes e sistemas deposicionais conduziram à subdivisão do Grupo Santa Bárbara na Sub-Bacia Camaquã Oriental em duas unidades: (i) Formação Passo da Capela, unidade formada por turbiditos de leques subaquosos e (ii) Formação Rincão dos Mouras, unidade constituída por arenitos e conglomerados de leques aluviais e sistemas fluviais entrelaçados. A Formação Passo da Capela apresenta a maior espessura já verificada dentro do Grupo Santa Bárbara, alcançando cerca de 4000 m na Sub-Bacia Camaquã Oriental. A principal associação litofaciológica compreende conglomerados e arenitos grossos depositados por fluxos gravitacionais de massa subaquosos e arenitos e ritmitos gerados por correntes de turbidez, representativos de ambiente de leques subaquoso. Estes depósitos de leques intercalam-se com arenitos e ritmitos de ambiente marinho (indicado por minerais de glauconita), dominado por ondas de tempestades. A Formação Passo da Capela apresenta, ainda, intercalações de dois níveis de sismitos indicativos de atividade tectônica sin-sedimentar. A Formação Rincão dos Mouras (até $2000 \mathrm{~m}$ ), comum a todas as sub-bacias, constitui-se de conglomerados e arenitos conglomeráticos depositados principalmente por sistemas de leques aluviais proximais a distais dominados por processos de enchentes em lençol que passam para depósitos fluviais de rios entrelaçados de alta energia. As análises de proveniência e paleocorrentes indicam que os altos de Caçapava do Sul e da Serra das Encantadas serviram como área fonte para esses depósitos aluviais, sugerindo o soerguimento destes altos durante a evolução do preenchimento sedimentar desta unidade. Desta forma, a Formação Rincão dos Mouras marca a compartimentação tectônica da Bacia do Camaquã em sub-bacias através do soerguimento de altos internos. Foram reconhecidas três seqüências deposicionais na Sub-Bacia Camaquã Oriental. A Seqüência 1 compõe-se principalmente de turbiditos arenosos indicativos de trato transgressivo (nível de mar alto). A Seqüência 2 é constituída por sistemas de leques subaquosos representativos do trato de mar baixo, que são sobrepostos por uma sucessão marinha com depósitos de águas rasas- tratos transgressivo e de mar alto. A Seqüência 3 marca a reorganização tectônica da Bacia do Camaquã que passa a ser individualizada em sub-bacias separada pelo alto de embasamento da Serra das Encantadas na Sub-Bacia Camaquã Oriental. O soerguimento de altos internos propiciou a instalação de sistemas de leques aluviais e de planícies fluviais que caracterizam as sucessões basais desta seqüência. A integração dos dados obtidos aponta que o Grupo Santa Bárbara e, por extensão todo o Supergrupo Camaquã, depositou-se em uma bacia extensional tipo rifte, com falhas de borda de rejeito normal ou oblíquo, sem grandes rejeitos direcionais, cujo preenchimento sedimentar foi controlado, sobretudo, pelos seguintes fatores: subsidência tectônica, aporte sedimentar e padrões de transporte sedimentar — sob influência das variações relativas do nível do mar.
\end{abstract}

Palavras-chave: Sub-Bacia Camaquã Oriental, Grupo Santa Bárbara, Ediacarano, análise de fácies, proveniência, paleocorrentes

Abstract STRATIGRAPHIC ANALYSIS OF THE SANTA BÁRBARA GROUP (EDIACARAN) IN THE EASTERN CAMAQUA SUB-BASIN, RS. In the Eastern Camaquã Sub-basin the Santa Bárbara Group (Ediacaran) is over 6,000 $\mathrm{m}$ thick. The group is represented by a sucession of marine to coastal sandstones and rhythmites and alluvial conglomerates and sandstones, disposed in progradational-retrogrational cycles. Detailed stratigraphic studies of paleoenvironments, facies and depositional systems have lead to the subdivision of the Santa Bárbara Group, in the Eastern Camaquã Sub-basin, into two formations: (i) Passo da Capela Formation: unit composed of subaqueous fan turbidites and (ii) Rincão dos Mouras Formation: alluvial fan and pebbly braided river unit. The Passo da Capela Formation is the thickest unit of the Santa Bárbara Group, reaching a thickness of about 4,000m in the eastern sub-basin. The main lithofacies is composed of conglomerates and coarse-grained sandstones deposited by subaqueous gravity mass flows, and sandstones and rhythmites deposited by turbidity currents, in subaqueous fans. These fan deposits are intercalated with marine sandstones and rhythmites (indicated for glauconita minerals) dominated by storm waves. This formation also contains two main levels of seismic deposits which indicate the action of syn-sedimentary tectonic events. The Rincão dos Mouras Formation, up to 2,000m thick, is present in all sub-basins, and is composed of conglomerates and conglomeratic sandstones accumulated mainly in alluvial fans and braided rivers. Stratigraphic analyses show that basement highs must have been the source areas for these alluvial deposits, which suggest that these areas were up-lifted during the course of sedimentation of this unit. The Rincão dos Mouras Formation therefore records the separation of the Camaquã Basin into sub-basins through uplift of internal highs. Three depositional sequences were recognized in the Eastern Camaquã Sub-basin. The Sequence 1 is composed mainly of turbidite sandstones which represent the transgressive and highstand tracts. The Sequence 2 is formed by subaqueous fan systems, representing the lowstand tract, and is overlained by marine succession with shallow-water deposits- transgressive and highstand tracts. The Sequence 3 registers the tectonic reorganization of the Camaquã Basin which becomes separated into three sub-basins by the elevation of the Serra das Encantadas basement high. This uplift lead to the installation of alluvial fans and flood plains which are typical of this sequence. The integration of the data also suggests that the Santa Bárbara Group and, by extension, the entire Camaquã Supergroup, was deposited in an extensional rift, whose border faults had normal or oblique throw without large slip movements, and whose sedimentary infilling was controlled mainly by tectonic subsidence, the clastic supply and the sedimentary transport under the influence of sea level changes.

Keywords: Eastern Camaquã Sub-basin, Santa Bárbara Group, Ediacaran, facies analysis, provenance, paleocurrents

1 - Depto. de Geologia, Centro de Tecnologia e Geociências, Universidade Federal de Pernambuco, Recife, PE. fone: (+55 81) 2126-8240, FAX: (+55 81) $2126-8234$. PRH-26 (ANP/FINEP/UFPE). E-mail: gelson.fambrini@ufpe.br

2 - Departamento de Geologia Sedimentar e Ambiental (GSA), Instituto de Geociências, Universidade de São Paulo, São Paulo, SP, Brasil. E-mail: romalino@usp.br 
INTRODUÇÃO O intervalo situado entre o fim do Neoproterozóico e início do Paleozóico na porção sudeste da Plataforma Sul-Americana registra a presença de ocorrências sedimentares e vulcano-sedimentares geradas após os eventos orogênicos do Ciclo Brasiliano. Tais ocorrências foram originadas em bacias tectônicas alongadas segundo direção variável entre NNE a ENE associadas a falhas de mesma orientação do embasamento sobre o qual se situam. Os depósitos destas bacias são formados por espessas sucessões de conglomerados, arenitos e pelitos de ambientes continentais, costeiros e marinhos, freqüentemente associados com rochas vulcanogênicas de afinidade alcalina.

Conforme previamente apontado por Almeida (1969), a mais completa e melhor exposta é a Bacia do Camaquã, situada na porção centro-sul do estado do Rio Grande do Sul (Fig. 01), onde recobre rochas pré-cambrianas do embasamento e compreende espessas sucessões siliciclásticas e vulcanogênicas, como regra classificadas como molassas do fim da Orogenia Brasiliana (Almeida 1969, Fragoso-Cesar et al. 1982, 1984, FragosoCesar 1984, 1991), posteriormente interpretadas como registros de bacias transcorrentes (Oliveira \& Fernandes 1991, Machado \& Sayeg 1992, Caravaca 1998), ou vinculadas a retro-arco de antepaís do orógeno deste ciclo no sul do Brasil (Gresse et al. 1996). Em trabalhos recentes, elementos de campo têm indicado que a Bacia do Camaquã é produto de evolução extensional, constituindo um sistema de riftes possivelmente sem vinculação com o Ciclo Brasiliano (Fragoso-Cesar et al. 2000, 2001, Almeida 2001, Fambrini et al. 2001, Fambrini 2003), atualmente interpretado como um sistema anorogênico (Fragoso-Cesar et al. 2002, 2003).

A Bacia do Camaquã compõe um sistema intracontinental de riftes de direção preferencial NNE-SSW preenchidos por depósitos espessos (>8000 m) do Supergrupo Camaquã, de idade ediacarana (Fragoso-Cesar et al. 2003, Janikian et al. 2003, Fambrini 2003), organizados, da base para o topo, nas seguintes unidades: (i) Grupo Maricá, unidade basal, espessa sucessão siliciclástica marinha e aluvial; (ii) Grupo Bom Jardim, originado em ambientes continentais subaquáticos e subaéreos, composto por rochas siliciclásticas, vulcanoclásticas e vulcânicas de composição intermediária a básica; (iii) Formação Acampamento Velho, composta por rochas vulcânicas e piroclásticas riolíticas a traquiticas; (iv) Grupo Santa Bárbara, predominantemente siliciclástico $(6000 \mathrm{~m})$, formado após as manifestações vulcânicas e depositado em ambientes aluviais e marinhos costeiros; (v) Grupo Guaritas, constituído por rochas siliciclásticas depositadas em ambientes aluviais e eólicos e (v) Suíte Intrusiva Rodeio Velho, representada por corpos tabulares de composição intermediária a básica. Estas unidades não apresentam metamorfismo regional e reúnem deformações de caráter essencialmente rúptil.

A Bacia do Camaquã foi compartimentada em sub-bacias durante a evolução tectono-sedimentar devido ao soerguimento sin-deposicional dos altos de Caçapava do Sul e da Serra das Encantadas (Fig. 01). A Sub-Bacia Camaquã Ocidental, localizada a oeste do Alto de Caçapava do Sul, é preenchida pelas sucessões do Grupo Maricá, do Grupo Bom Jardim, da Formação Acampamento Velho e do Grupo Santa Bárbara, contendo as localidades tipo destas unidades, exceto o Grupo Bom Jardim. Entre os altos de Caçapava do Sul e da Serra das Encantadas expõe-se a Sub-Bacia Camaquã Central (Fambrini et al. 2005), localidade-tipo do Grupo Bom Jardim, do Grupo Guaritas e da Suíte Intrusiva Rodeio Velho, além de conter diversas exposições do Grupo Santa Bárbara (e.g. Minas do Camaquã). À leste do Alto da Serra das Encantadas, abrangendo as regiões do Arroio Boici, Vale do Piquiri, Capané e Rincão dos Mouras, aflora a Sub-Bacia Camaquã Oriental, onde apenas o Grupo Santa Bárbara ocorre.

As sucessões de conglomerados e arenitos que afloram na
Sub-Bacia Camaquã Oriental foram pioneiramente definidas como Formação Arroio dos Nobres do Grupo Bom Jardim por Ribeiro et al. (1966) e por Tessari \& Picada (1966). A Formação Arroio dos Nobres foi dividida em duas unidades segundo estes autores: Membro Mangueirão, constituído por ritmitos psamopelíticos, e o Membro Vargas, representado por conglomerados e arenitos conglomeráticos. A seguir, esta unidade foi identificada por Tessari \& Giffoni (1970) na região do Arroio Boici.

Sob enfoque litoestratigráfico, como resultado de investigações regionais em todas as sub-bacias e de detalhe em diversos trechos destas ocorrências, Fambrini et al. (1996), Fambrini (2003) e Fambrini et al. (2005) constataram que correlações estratigráficas, estruturais, litológicas, paleoambientais e de variação do nível relativo do mar indicam que as unidades Santa Bárbara e Arroio dos Nobres são correlacionáveis, ocupando mesma paleogeografia em contexto tectono-sedimentar similar. Tendo em vista que a designação Santa Bárbara (definida informalmente por Robertson em 1961, manuscrito publicado em 1966) possui prioridade sobre a designação Arroio dos Nobres, sugere-se que esta unidade passe a ser denominada de Grupo Santa Bárbara (Fambrini et al. 2005).

Este trabalho corrobora a proposta de Fambrini (2003) e Fambrini et al. (2005) na qual as unidades litoestratigráficas aflorantes na Sub-Bacia Camaquã Oriental passaram a ser denominadas de Grupo Santa Bárbara, abandonando-se a designação Formação Arroio dos Nobres, então consagrada para tais depósitos sedimentares.

SUB-BACIA CAMAQUÃ ORIENTAL A Sub-Bacia Camaquã Oriental (Fig. 02) situa-se na borda leste da Bacia do Camaquã e ocupa uma depressão tectônica alongada segundo a direção preferencial NNE-SSW, preenchida predominantemente por sucessões siliciclásticas imaturas que, localmente, ultrapassam $6000 \mathrm{~m}$ de espessura. Limita-se a leste e oeste com

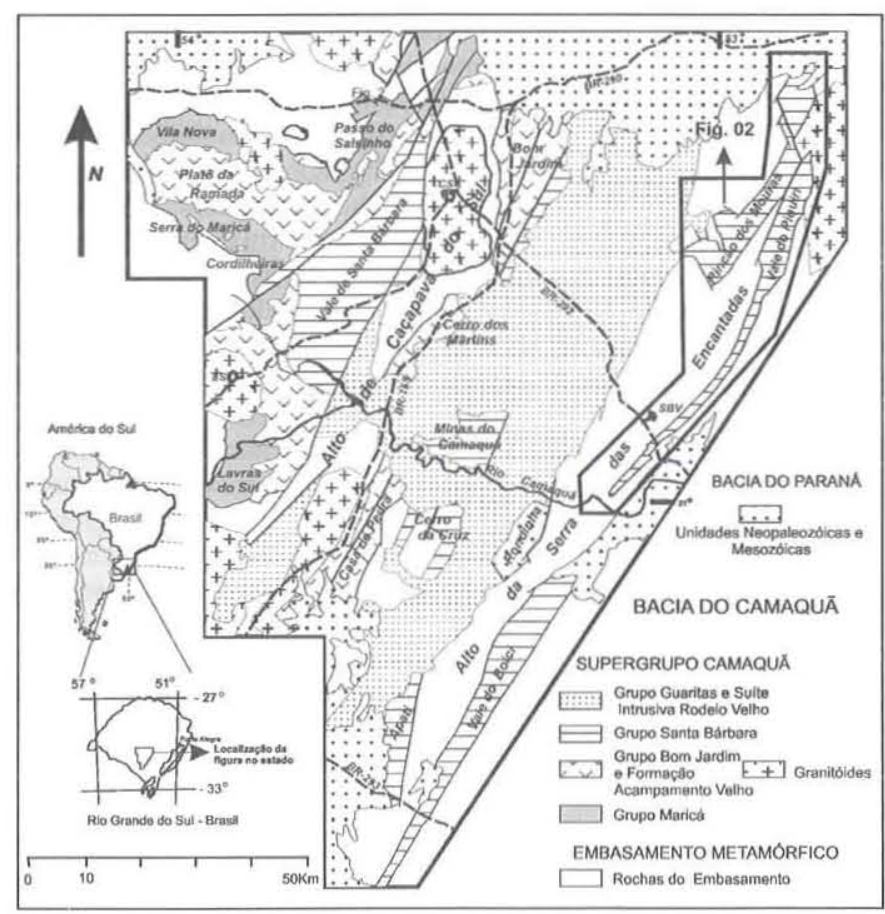

Figura 01- Esboço geológico das unidades neoproterozóicas e eopaleozóicas do Rio Grande do Sul, com destaque para as unidades que constituem o Supergrupo Camaquã. Cidades: CSCaçapava do Sul; LS-Lavras do Sul; SBV-Santana da Boa Vista (modificada de Fragoso-Cesar et al. 2000). 
as rochas metavulcânicas e metassedimentares do Complexo Porongos na porção intermediária a meridional por contato tectônico, principalmente falhas normais a oblíquas de direção NE e NNE, posteriormente reativadas como falhas transcorrentes que colocaram altos do embasamento em meio aos depósitos sedimentares e pelo embasamento do Granito Encruzilhada do Sul em sua extremidade setentrional. A norte é recoberta por sedimentos paleozóicos da Bacia do Paraná. Na Sub-Bacia Camaquã Oriental o Supergrupo Camaquã acha-se representado por rochas eminentemente sedimentares do Grupo Santa Bárbara, que se assentam diretamente sobre o embasamento ígneo-metamórfico. O Grupo Santa Bárbara encontra-se basculado por tectônica de blocos associada às falhas normais a oblíquas, sendo comuns mergulhos entre $25^{\circ}$ e $80^{\circ}$ para oeste e, em parte da porção norte da exposição, para sudoeste. Localmente, no contato com o Sienito Piquiri, no extremo nordeste da sub-bacia, a relação de contato dá-se através de discordância litológica indicando a proximidade da área fonte e os produtos dela derivados.

LITOESTRATIGRAFIA Considerando-se critérios litoestratigráficos, no Grupo Santa Bárbara na Sub-Bacia Camaquã Oriental, são reconhecidas duas unidades mapeáveis na escala 1:25.000. Da base para o topo, destacam-se: (i) Formação Passo da Capela formada por brechas, conglomerados e arenitos de leques subaquáticos e turbiditos proximais, turbiditos distais e tempestitos marinhos de ambiente de costa-afora e (ii) Formação Rincão dos Mouras constituída por conglomerados e arenitos grossos a conglomeráticos aluviais.

Formação Passo da Capela Na Sub-Bacia Camaquã Oriental, esta unidade apresenta a maior espessura já verificada dentro do Grupo Santa Bárbara, superando 4000 m no Vale do Piquiri. A Formação Passo da Capela, conforme aqui definida, compreende os depósitos eminentemente siliciclásticos subaquáticos que afloram, por exemplo, no Vale do Piquiri (Fig. 02), e se situam estratigraficamente abaixo dos arenitos e conglomerados aluviais sobrepostos.

A Formação Passo da Capela aflora desde a região em torno da cidade de Santana da Boa Vista a sul até a região de Capané a norte (Fig. 02). A localidade-tipo eleita para esta unidade é um excelente afloramento natural escavado pelo arroio Olaria em uma antiga passagem desta drenagem conhecida como Passo da Capela, localizada nas proximidades da cidade de Santana da Boa Vista. Neste local, afloram tanto os arenitos e ritmitos como os conglomerados e arenitos grossos, gerados em todos os ambientes descritos e reconhecidos para a formação, ou seja, desde correntes de turbidez até depósitos formados por ação de ondas de tempestades, adiante discutidos.

Os trabalhos de mapeamento geológico, descrição litológica, análise estratigráfica de fácies, proveniência e paleocorrentes e análise petrográfica realizados na Sub-Bacia Camaquã Oriental nas regiões do Vale do Piquiri/Rincão dos Mouras/Capané possibilitaram uma subdivisão comum da Formação Passo da Capela nesta sub-bacia em três associações de fácies: Associação de Fácies Inferior; Associação de Fácies Intermediária e Associação de Fácies Superior.

Associação de Fácies Inferior A Associação de Fácies Inferior aflora na região do curso médio do Arroio dos Nobres, além de isoladas exposições na localidade do Passo da Capela e próximo ao Cerro da Picada (Fig. 02). Esta unidade consiste basicamente de arenitos e ritmitos formados pela intercalação de arenitos finos maciços a laminados com siltitos laminados dispostos em camadas rítmicas tabulares de grande continuidade lateral e espessura, que perfazem espessura entre $1000 \mathrm{~m}$ e $1500 \mathrm{~m}$. Nesta sucessão interpõem-se, em seus níveis basais, quatro camadas de tufitos félsicos e, em dois níveis estratigráficos que marcam limites de seqüências, intervalos de depósitos interpretados como sismitos (Fig. 03). As fácies predominantes (Tabela 1) são de arenitos finos a muito finos, micáceos, maciços (fácies Am) a laminados (fácies Al), bem litificados (Fig. 04A). Por vezes, o topo e/ou a base podem estar ondulados devido à associação com arenitos finos com laminação cruzada cavalgante de base reta (formada a partir de correntes) da Fácies Ac. Os arenitos maciços apresentam camadas individuais mais espessas (até 30 $\mathrm{cm}$ ) e podem estar silicificados, fato este que sustenta pequenas cristas no terreno; já os laminados são siltosos, pouco argilosos, por vezes contendo delgadas películas de argila (mud drapes) sub-paralelas à laminação plano-paralela conspícua, de espessura centimétrica (da ordem de 2 a $8 \mathrm{~cm}$ ) (Fig. 04B, C). Subordinadamente ocorrem siltitos com laminação plano-paralela (fácies $\mathrm{Sl}$ ), dispostos em finas camadas centimétricas e arenitos finos maciços com grânulos e pequenos seixos (fácies Am). É característica desta unidade a presença de arenitos finos a muito finos com laminações contorcidas (fácies Alc, Fig. 04D) intercalados em arenitos cujas camadas não exibem qualquer deformação em dois níveis estratigráficos principais, um abaixo dos conglomerados da Associação de Fácies Intermediária (adiante discutida), e outro imediatamente abaixo dos conglomerados fluviais da Formação Rincão dos Mouras (Fig. 03). Também existe um nível próximo do contato com o embasamento. No afloramento do Passo da Capela (Fig. 05A, B) ocorrem camadas de arenitos com laminações intensamente contorcidas (Fig. 05C, D) entre outras que não exibem deformação, e mostram diversas feições decorrentes, provavelmente, de uma atividade sísmica sin-sedimentar, sendo assim chamados de sismitos (sensu Seilacher 1969, Obermeier et al. 1990, Vittori et al. 1991, Obermeier 1996), tal como caracterizado em trabalhos recentes (FragosoCesar et al. 2001, Fambrini et al. 2001, Fambrini 2003). No Vale do Piquiri, a norte da região do Passo da Capela, foram observadas abundantes dobras que não obedecem a nenhum padrão. Ao mesmo tempo, esta deformação está restrita a um set de camadas, apesar de se prolongarem por grande distância lateral (até $10 \mathrm{~km}$ ). Além dessas, ocorrem também estruturas como diques clásticos (Fig. 06), camadas rompidas e slumps.

Nesta associação ocorrem, ainda, finas intercalações rítmicas de siltitos em geral maciços e arenitos extremamente finos siltosos laminados bem como maciços. Quando laminadas, ambas litologias possuem laminação plano-paralela e, por vezes, ondulada. Em direção ao topo da sucessão surgem corpos lenticulares de até $15 \mathrm{~cm}$ de espessura de arenitos médios, por vezes grossos, com laminações cruzadas truncadas por ondas (no sentido de Lavina et al. 1985 para designar truncamentos com comprimento de onda menor que $1 \mathrm{~m}$ ), as chamadas $\mathrm{mi}$ cro-hummockies de Dott \& Bourgeois (1982), de base e topo ondulados, interpretados como tempestitos. No topo das camadas de arenitos médios são abundantes as marcas onduladas do tipo simétrico com 2 a $6 \mathrm{~cm}$ de comprimento de onda e padrão de interferência sugestivo de oscilação. As camadas de arenitos médios espessam-se em direção ao topo da sucessão.

A Associação de Fácies Inferior apresenta intercalações de lentes rudáceas delgadas (espessura máxima de aproximadamente $50 \mathrm{~m}$ ) restritas à base da unidade, constituídas por brechas e, subordinadamente, conglomerados sustentados por arcabouço, por sua vez compostos de clastos muito angulosos e tabulares de esfericidade baixa, da granulometria seixo até calhau, espalhados pela matriz mal selecionada muito fina a grossa, sem organização alguma evidente (Fig. 07). Petrograficamente, os clastos da brecha são de filito sericítico (maioria), quartzito fino, milonito, gnaisse, granito e quartzo de veio (Fambrini 2003). Estes depósitos rudáceos lenticulares basais, cartográfica e volumetricamente pouco expressivos, ocorrem como lentes de es- 




Figura 02- Mapa geológico do Grupo Santa Bárbara na Sub-Bacia Camaquã Oriental (modificado de Fambrini 2003). 
pessura reduzida ( $50 \mathrm{~m}$ nas proximidades do Cerro do Alemão) ao longo do Vale do Piquiri, na região de Santana da Boa Vista, na região em torno do Cerro do Bicho e, a sul do rio Camaquã, na borda leste da ocorrência do Arroio Boici.

As delgadas intercalações de arenitos finos maciços, laminados e com laminações cruzadas cavalgantes e siltitos foram interpretados como depósitos gerados por correntes de turbidez de baixa densidade, segundo preceitos de Lowe (1982), e provavelmente originados abaixo da ação de ondas de tempestade em ambiente de costa-afora (offshore), consistindo de turbiditos clássicos (sensu Walker 1992) relacionados a uma sucessão retrogradacional. As brechas lenticulares basais, devido à associação com os turbiditos, sugerem condições subaquáticas de deposição, provavelmente nas partes proximais de um leque subaquoso.

Os depósitos de arenitos com laminações contorcidas e dobras sem padrão foram interpretados como sismitos no sentido de Vittori et al. (1991). Em analogia aos estudos de Sims (1973), Mills (1983), Hempton \& Dewey (1983), Obermeier (1996), Mohindra \& Thakur (1998), Rossetti (1999), Rossetti \& Góes (2000), Rodríguez-Pascua et al. (2000), dentre outros, interpretou-se que esse conjunto de estruturas foi gerado pela ação de sismos, possivelmente de magnitude entre 5,5 e 6,5 na escala Richter, causando liqüefação dos sedimentos e gerando estruturas de injeção em camadas adjacentes, por vezes descritas como gretas de contração (Oliveira \& Fernandes 1991, Caravaca et al.
2001). A constatação de ocorrência de pelo menos dois intervalos de sismitos indicam atividade sísmica na bacia, conforme antecipado por Fragoso-Cesar (1984), Lavina et al. (1985) e Paim et al. (1986). Por outro lado, a presença de sismitos próximo do contato com a Associação de Fácies Intermediária sugere que, provavelmente, abalos sísmicos foram os detonadores destes fluxos de gravidade e das correntes de turbidez que geraram os depósitos de leque subaquoso. Em adição, a presença de sismitos em intervalos imediatamente abaixo de superfícies erosivas limitantes de seqüências sugere a atuação da tectônica concomitante às variações eustáticas no controle da deposição das seqüências deposicionais.

Associação de Fácies Intermediária A Associação de Fácies Intermediária concentra-se na porção meridional e intermediária na região do Vale do Piquiri, em cotas mais elevadas ( 250 a 370 m), mas ocorrem também na porção setentrional em ocorrências isoladas na localidade do Passo do Moirão e nos flancos de estrutura sinclinal na região de Capané. Esta associação consiste de conglomerados maciços a estratificados, com intercalações subordinadas de arenitos conglomeráticos (Fig. 08). Os conglomerados maciços (fácies Cma) são sustentados por matriz e também por arcabouço (Tabela 1). Estes conglomerados possuem como característica a desorganização do depósito realçada pela diferença entre a matriz fina e os clastos do tamanho matacão, que atingem dimensão máxima de até 3,20 m. A matriz é composta por uma mistura heterogênea de areia, silte e grânu-

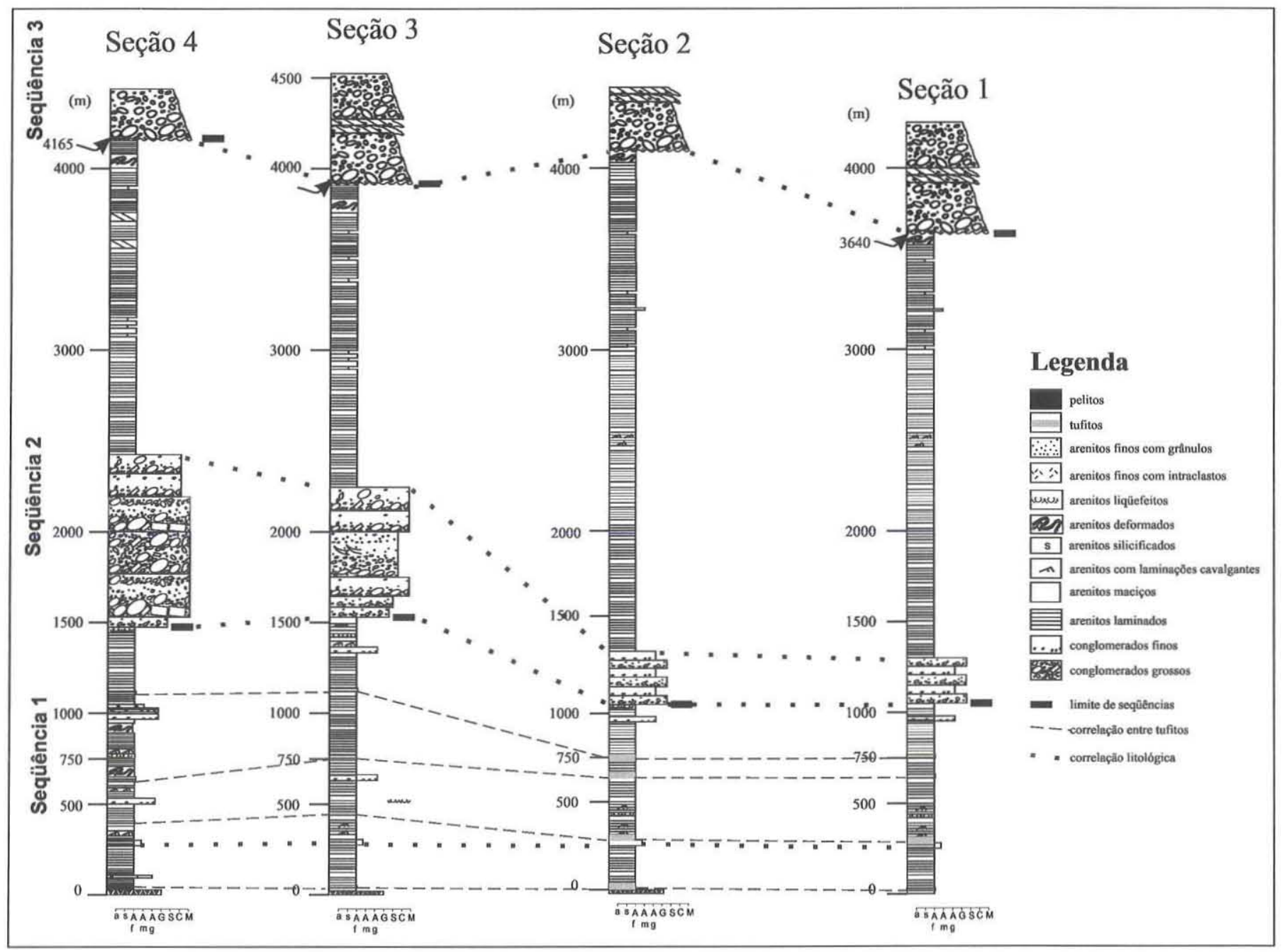

Figura 03 - Seções correlacionadas da Formação Passo da Capela. 
Tabela 1 - Análise das fácies encontradas na Formação Passo da Capela no Vale do Piquiri.

\begin{tabular}{|c|c|c|c|}
\hline Código & Fácies & Descrição & Mecanismo Deposicional \\
\hline$A m$ & Arenitos finos maciços & $\begin{array}{l}\text { Arenitos finos maciços, localmente variando para } \\
\text { arenito médio. As camadas tabulares individuais de } \\
\sim 15 \mathrm{~cm} \text { de espessura encontram-se bem litificadas } \\
\text { e possuem grande extensão lateral. O topo e a base } \\
\text { podem, ocasionalmente, estar ondulados. }\end{array}$ & $\begin{array}{l}\text { Depósitos de corrente de turbidez subaquática, } \\
\text { similares aos dos arenitos do horizonte A da } \\
\text { seqüencia de turbiditos clássicos de Bouma } \\
\text { (1962). }\end{array}$ \\
\hline$A l$ & $\begin{array}{l}\text { Arenitos muito finos } \\
\text { laminados. }\end{array}$ & $\begin{array}{l}\text { Arenitos muito finos laminados, siltosos e pouco } \\
\text { argilosos, ocasionalmente com delgadas películas } \\
\text { de argila (mud drapes), dispostas paralelamente à } \\
\text { laminação. As camadas possuem espessura média } \\
\text { de } 7 \mathrm{~cm} \text {. }\end{array}$ & $\begin{array}{l}\text { Análogo ao dos arenitos do horizonte B da } \\
\text { seqüencia de turbiditos clássicos de Bouma } \\
\text { (1962). Depositados sob regime de fluxo } \\
\text { inferior ou superior. }\end{array}$ \\
\hline$S l$ & Siltitos laminados & $\begin{array}{l}\text { Siltitos com laminação plano-paralela, organizados } \\
\text { em camadas de } 5 \mathrm{~cm} \text {. }\end{array}$ & $\begin{array}{l}\text { Material em suspensão das correntes de } \\
\text { turbidez. }\end{array}$ \\
\hline$A g$ & $\begin{array}{l}\text { Arenitos finos com } \\
\text { grânulos }\end{array}$ & $\begin{array}{l}\text { Arenitos finos com grânulos e pequenos seixos, } \\
\text { por vezes contém delgadas películas de argila (mud } \\
\text { drapes) }\end{array}$ & $\begin{array}{l}\text { Neste estágio a corrente de turbidez carrega os } \\
\text { sedimentos muito finos até grânulos. }\end{array}$ \\
\hline Acg & Arenito conglomerático & $\begin{array}{l}\text { Arenitos conglomeráticos com grânulos e } \\
\text { pequenos seixos, matriz de arenito médio a grosso. } \\
\text { Estratificação plano-paralela. }\end{array}$ & $\begin{array}{l}\text { Indicam o início da perda de competência dos } \\
\text { fluxos turbidíticos. }\end{array}$ \\
\hline $\mathrm{Ce}$ & $\begin{array}{l}\text { Conglomerados com } \\
\text { estratificação plano- } \\
\text { paralela }\end{array}$ & $\begin{array}{l}\text { Conglomerados polimíticos, organizados em } \\
\text { camadas tabulares de grande extensão lateral, } \\
\text { sustentados por arcabouço, com granulometria de } \\
\text { seixo a calhau }\left(\phi_{\text {máx. }}=10 \mathrm{~cm}\right) \text {, cujos clastos são } \\
\text { subangulosos a subarredondados. Matriz de arenito } \\
\text { grosso a médio e estratificação plano-paralela. }\end{array}$ & $\begin{array}{l}\text { Depósitos de fluxos canalizados, localizados } \\
\text { nas porções intermediárias de leques } \\
\text { subaquosos. }\end{array}$ \\
\hline $\mathrm{Cm}$ & $\begin{array}{l}\text { Conglomerados } \\
\text { maciços }\end{array}$ & $\begin{array}{l}\text { Conglomerados sustentados por arcabouço, maciços, } \\
\text { com fragmentos em geral subangulosos variando } \\
\text { de seixo a matacão (até 1,3m), mal selecionados, } \\
\text { A matriz é mal selecionada, grossa, com grânulos } \\
\text { subangulosos. A grande dimensão dos clastos é } \\
\text { caraterística. }\end{array}$ & $\begin{array}{l}\text { Depósitos de fluxos de detritos, localizados nas } \\
\text { porções proximais de leques subaquosos. }\end{array}$ \\
\hline Ams & $\begin{array}{l}\text { Arenitos maciços } \\
\text { silicificados. }\end{array}$ & $\begin{array}{l}\text { Arenitos muito finos, maciços, muito silicificados, } \\
\text { em camadas individuais de } \sim 50 \mathrm{~cm} \text {, de grande } \\
\text { continuidade lateral. }\end{array}$ & $\begin{array}{l}\text { Depósitos associados às correntes de turbidez, } \\
\text { posteriormente silicificados. }\end{array}$ \\
\hline$T f$ & Tufitos & $\begin{array}{l}\text { Rocha vulcânica, de textura afanítica, com vidro } \\
\text { vulcânico, piroclastos e minúsculos fragmentos } \\
\text { líticos. }\end{array}$ & Associado à atividade vulcânica explosiva \\
\hline$A c$ & $\begin{array}{l}\text { Arenitos argilosos } \\
\text { com laminações } \\
\text { cavalgantes. }\end{array}$ & $\begin{array}{l}\text { Arenitos muito finos argilosos, em camadas } \\
\text { individuais, de grande continuidade lateral e } \sim 4 \mathrm{~cm} \\
\text { de espessura, formando pacotes de até } 25 \mathrm{~cm} \text {. No } \\
\text { topo estas possuem marcas onduladas assimétricas, } \\
\text { apresentando internamente laminações cruzadas } \\
\text { (climbing ripples) de base reta. }\end{array}$ & $\begin{array}{l}\text { Depósitos de correntes subaquosas onde atuam } \\
\text { conjuntamente processos de deposição de } \\
\text { material de tração e decantação. }\end{array}$ \\
\hline
\end{tabular}

los. Outra peculiaridade destes conglomerados é a abundância de fragmentos de rochas da própria bacia, em especial arenitos finos e médios e conglomerados das unidades sotopostas. Em uma ocorrência, anteriormente descrita e interpretada por Fragoso-Cesar (1984), encontra-se um grande fragmento de uma camada de arenito fino com aproximadamente $8 \mathrm{~m}$ de diâmetro máximo e espessura em torno de $80 \mathrm{~cm}$ que, ao ser arrancado do fundo da bacia, fragmentou-se em diversas partes com dimensão máxima de $1,30 \mathrm{~m}$, cujos fragmentos, se somados, ultrapassam $8 \mathrm{~m}$ de comprimento (Fig. 08G).

Os conglomerados maciços (fácies Cmc) sustentados por arcabouço (fragmentos $>50 \%$ conforme Collinson \& Thompson 1989) são extremamente mal selecionados e possuem clastos predominantemente da granulometria calhau a matacão, que localmente alcançam diâmetro superior a $1 \mathrm{~m}\left(\phi_{\max }=1,3 \mathrm{~m}\right)$. Os clastos alternam-se de angulosos a subarredondados, com predomínio dos primeiros (inclusive com arestas preservadas), e possuem em sua maioria baixa esfericidade. As camadas de conglomerados são métricas e aparentemente tabulares. Nestas destacam-se matacões subangulosos de arenitos finos, por vezes silicificados, de aspecto tabular, alinhados em meio à estrutura maciça da rocha. Estes depósitos situam-se preferencialmente nas porções proximais.

Devido às características intrínsecas dos depósitos, tais como desorganização, má seleção, coexistência de grânulos com matacões de até $3,20 \mathrm{~m}$, e ausência de estruturas trativas, estes foram interpretados como originados a partir de fluxos de detritos (debris flow). Com isso, fragmentos de grandes dimensões puderam ser transportados em suspensão, devido à coesão de uma matriz representada pela mistura intersticial de água e sedimentos finos.

Nesta unidade destacam-se, ainda, conglomerados estratificados e intercalações de arenitos conglomeráticos e até arenitos finos que incorporam conjuntos de camadas com granodecrescência ascendente e lateral conspícua. Os conglomerados estratificados (fácies Ce) são organizados, polimíticos, sustentados 

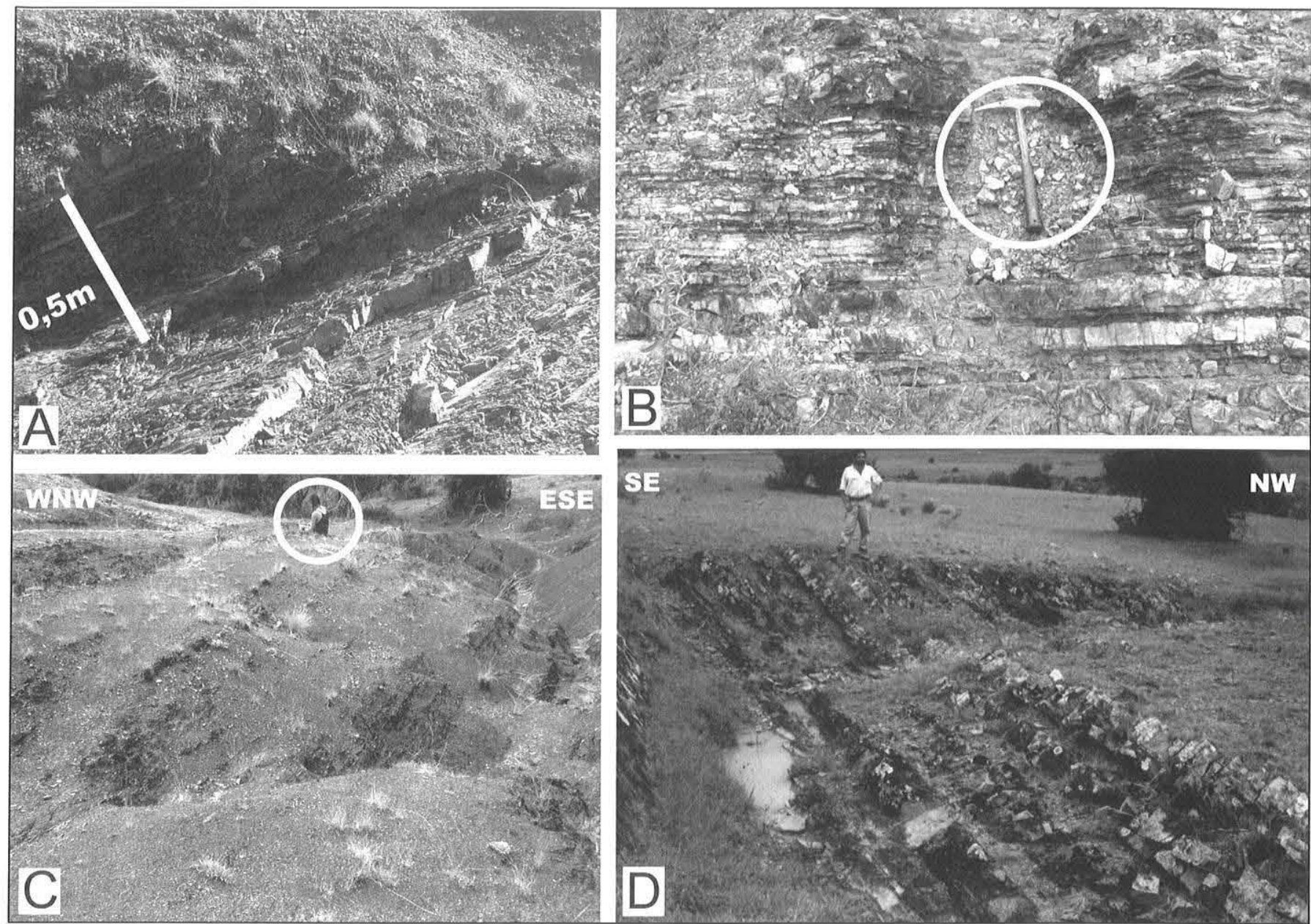

Figura 04 -Aspecto dos turbiditos de leque intermediário (outer-fan) da Formação Passo da Capela mostrando a fina intercalação de arenitos e siltitos $(A, B$ e $C$ ) e, em $D$, a presença de camadas mais espessas de arenitos.

por arcabouço, dispostos em pacotes decimétricos a métricos (70 cm a 1,5 m de espessura), com estratificação plano-paralela denotada por gradação no tamanho ou seleção dos clastos. Os fragmentos encontram-se fortemente imbricados, variam em tamanho de seixo a matacão; ora são muito angulosos, ora subarredondados, e em geral, com baixo grau de esfericidade. A matriz é mal selecionada e constituída por arenito grosso a médio, por vezes com grânulos, cujos grãos mostram-se angulosos a subarredondados, com predomínio de subangulosos. Como estruturas sedimentares destacam-se estratificação plano-paralela e, localmente, estratificação cruzada do tipo acanalado. Nesta sucessão ocorrem, ainda, arenitos conglomeráticos (fácies Acg), maciços a estratificados, compostos por arenitos finos a grossos geralmente mal selecionados, dispostos em camadas que variam de 20 a $70 \mathrm{~cm}$. Como estruturas sedimentares nesta fácies ocorrem estratificação plano-paralela e, por vezes, estratificação cruzada tabular de pequeno porte. Tais características apontam para deposição em meio aquático.

Esta associação de fácies é interpretada como originada em ambiente subaquático (leque subaquoso) em posição proximal em relação à área fonte. Dentro deste contexto, inferiu-se para estes depósitos a posição fisiográfica relativa aos cânions submarinos, conforme Mutti (1992) e Mutti et al. (1999). Os conglomerados maciços indicam processos de sedimentação relacionados à participação de fluxos sedimentares de alta densidade (fluxos gravitacionais de massa subaquosos), de acordo com Middleton \& Hempton (1976) e Lowe (1982).
Associação de Fácies Superior A Associação de Fácies Superior compreende intercalações de diversos corpos de arenitos com siltitos (Fig. 09), de coloração castanha avermelhada característica. Os arenitos maciços (fácies Am) compõem-se de arenitos maciços, bem litificados, micáceos (placas de muscovita), dispostos em camadas tabulares centimétricas de grande continuidade lateral. Os arenitos finos laminados (fácies $\mathrm{Al}$ ) são siltosos e pouco argilosos, e se acham dispostos em camadas delgadas de 2 a $8 \mathrm{~cm}$. Localmente as camadas de arenitos apresentam topo e/ou base ondulado. A fácies de arenitos com laminações cruzadas cavalgantes (fácies Ac) caracteriza-se por arenitos muito finos argilosos de espessura centimétrica $(4 \mathrm{~cm})$ que, internamente, apresentam abundantes laminações cruzadas cavalgantes (climbing ripples) de base reta; o topo das camadas, por vezes, apresenta marcas onduladas assimétricas. Os arenitos laminados possuem delgadas galhas de argila (mud drapes) paralelas à laminação. A fácies de siltitos laminados (fácies Sl) constitui-se de siltitos de coloração ocre com laminação planoparalela conspícua, que se distribuem em camadas tabulares de grande continuidade lateral atingindo no máximo $6 \mathrm{~cm}$ de espessura. Em decorrência da laminação plano-paralela, o empastilhamento das camadas é acentuado. De ocorrência subordinada, a fácies Ams compreende arenitos finos, ocasionalmente médios, maciços, muito silicificados, com cor marrom acinzentada. Estes arenitos estão dispostos em camadas individuais muito espessas variando de $50 \mathrm{~cm}$ a $1 \mathrm{~m}$, sendo responsáveis pelas pequenas cristas do relevo em meio aos ritmitos. 


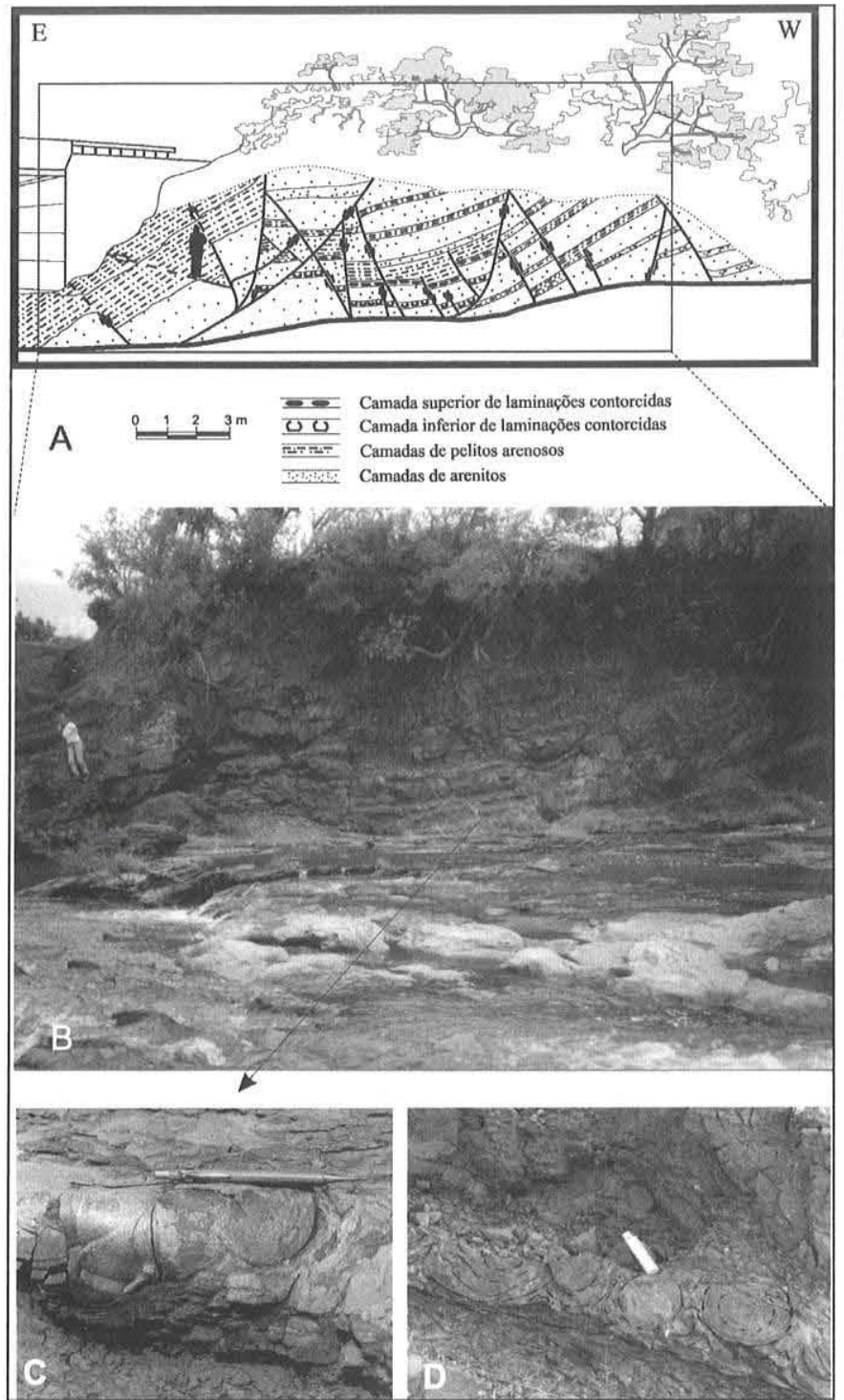

Figura 05 - Afloramento do Passo da Capela. A: Croqui da parede sul com destaque para as falhas sin-sedimentares, B: Foto geral da exposição salientando os niveis de laminações contorcidas, C e D: Pormenor das laminações contorcidas.

Formação Rincão dos Mouras Unidade bem caracterizada em todas as sub-bacias onde ocorre o Grupo Santa Bárbara e, possivelmente, registre eventos de individualização destas responsáveis pela atual configuração desta unidade na Bacia do Camaquã. A Formação Rincão dos Mouras abarca sucessões eminentemente granodecrescentes para o topo através de depósitos continentais aluviais que marcam a divisão do Grupo Santa Bárbara em sub-bacias separadas por altos do embasamento. Esta unidade expõe-se em larga área da porção noroeste do Vale do Piquiri, nas escarpas do Rincão dos Mouras e em bloco abatido junto à Serra da Boa Vista, e nas nascentes do Arroio Piquiri, cuja continuidade é obstruída por alto de embasamento.

A Formação Rincão dos Mouras tem sido interpretada como originada por leques aluviais proximais a distais dominados por processos de enchente em lençol que passam para depósitos fluviais de rios entrelaçados de alta energia (Fragoso-Cesar 1984, Fragoso-Cesar et al. 1984, Lavina et al. 1985, Fragoso-Cesar et al. 2000, Fambrini 2003), a despeito de outras interpretações (e.g. leque deltaico, Caravaca 1998), não confirmadas aqui.

A sucessão aluvial da Formação Rincão dos Mouras com- preende depósitos de (i) leques aluviais proximais a distais e (ii) sistema fluvial entrelaçado (Fig. 10), a seguir descritos.

Depósitos de leques aluviais proximais a distais Na porção inferior desta sucessão aparecem conglomerados maciços oligomíticos sustentados por matriz (fácies Cma), formada por argila e fragmentos detríticos de diversas formas e frações granulométricas, de ocorrência restrita a afloramentos isolados (Fig. 11). O arredondamento dos clastos é função de sua origem, com predomínio de formas esféricas arredondadas a subangulosas nos granitóides e tabulares e angulosas em rochas metamórficas.

À medida que se caminha lateral e verticalmente na sucessão, passam a existir intercalações de conglomerados desorganizados a pouco organizados (fácies $\mathrm{Cm}$ ), rudemente estratificados, sustentados por arcabouço da granulometria calhau a matacão $\left(\phi_{\text {máx. }}=74 \mathrm{~cm}\right.$ leucogranito róseo grosso equigranular). A matriz destes conglomerados é mal selecionada formada por arenito arcoseano grosso, com grãos de feldspato róseo, feldspato branco, quartzo, quartzitos e minerais pesados, e material fino. Os conglomerados exibem alguma seleção dos clastos (gradação normal) por estrato, o que gera a estratificação pouco desenvolvida observada. Por vezes, observou-se gradação inversa e imbricação de clastos.

Para o topo ( $2^{\circ}$ e $3^{\circ}$ megaciclos $)$ os conglomerados assumem organização (estratificados das fácies $\mathrm{Ce} \mathrm{e} \mathrm{Ct}$ ), passam a polimíticos, de geometria tabular, sustentados por arcabouço constituído por clastos da granulometria seixo a matacão, com intercalações decimétricas a métricas de arenitos conglomeráticos e arenitos com seixos e calhaus esparsos da fácies Acg (Fig. 11D). É a fácies dominante nesta porção de topo. A matriz destes conglomerados é mal selecionada formada por arenito arcoseano muito grosso a grosso com grânulos. Como estruturas sedimentares presentes destacam-se estratificação plano-paralela e cruzada dos tipos tabular e acanalado de pequeno e médio porte, com predomínio destas últimas formas de leito. Os fragmentos concentram-se em bolsões e nos estratos frontais das estratificações, constituídos de leucogranitos róseos e quartzo de veio, principalmente.

As características dos conglomerados maciços sustentados por matriz argilosa (fácies Cma) tais como desorganização interna, angulosidade dos clastos, granulometria até matacão, má seleção e imaturidade textural e mineralógica favorecem a ação de mecanismos de alta energia e alta viscosidade no transporte e acumulação destes depósitos. A alta viscosidade do fluxo foi inferida do baixo grau de maturidade textural e mineralógica, de seleção muito pobre onde fragmentos de dimensões maiores flutuam em meio a matriz fina e da ausência de estratificação interna, de acordo com os estudos de Blissenbach (1954), Bluck (1964), Bull (1964), Hooke (1967), Bull (1972), Gloppen \& Steel (1981), Nilsen (1982), Miall (1992), Blair \& McPherson (1994), Miall (1996), Blair (1999), entre outros. Conforme Hooke (1967) e Bull (1972) depósitos de fluxo de alta viscosidade encontram-se mais comumente junto ao ápice do leque, ou seja, em posição mais proximal. As características acima apontadas, associadas a estruturas como gradação inversa e imbricação de clastos, sugerem atuação de fluxos gravitacionais de massa tipo fluxo de detritos (debris-flow), de caráter proximal, com pouca matriz (sensu Shultz 1984). Os conglomerados maciços sustentados por arcabouço (fácies $\mathrm{Cm}$ ), excetuando-se a ausência de argila na matriz e o caráter sustentado por arcabouço dos depósitos, possuem as mesmas propriedades quanto à seleção, imaturidade textural e mineralógica, desorganização e arredondamento dos depósitos anteriores. Assim, representam depósitos de fluxo de detritos associados a leques aluviais em condições igualmente proximais em relação à área fonte. Deste modo, estes depósitos são interpretados como as fácies proxi- 


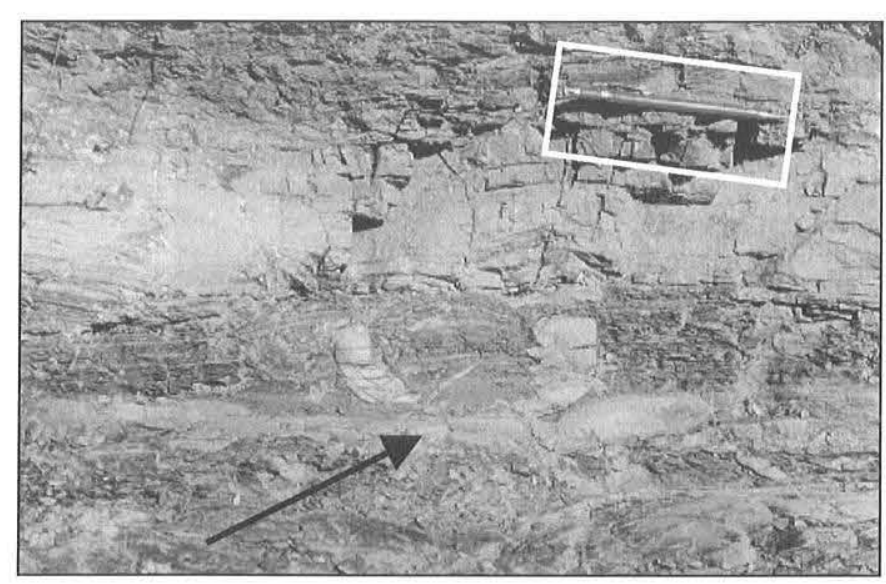

Figura 06 - Diques clásticos provocados por atividade sísmica sin-sedimentar da Formação Passo da Capela no Vale do Piquiri.



Figura 07 - Brechas sedimentares da base da Formação Passo da Capela no Vale do Piquiri junto ao contato com o Complexo Porongos. Destaque para seixos de filitos sericíticos (Fi) e xistos derivados desta unidade adjacente ao embasamento.

mais de sistemas de leques aluviais que se instalaram na bacia. Tal fato evidencia importante influência tectônica na sedimentação (bordas ativas) e assinalam um limite de seqüências fundamental para a correlação do Grupo Santa Bárbara em termos de tectono-seqüências.

A abundância de conglomerados estratificados sugere predomínio de fluxo desconfinado tipo enchentes em lençol de alta energia (sheet-flood) (Blair \& McPherson 1994). Subordinadamente, aparecem depósitos de correntes fluviais, provavelmente gerados em canais rasos e largos e/ou de grande migração late- ral. As superfícies de estratificação dos conglomerados Ce são realçadas por delgados níveis de arenitos grossos ou médios a conglomeráticos da fácies Acg $(30 \mathrm{~cm})$ contendo laminação plano-paralela ou estratificação cruzada tabular de pequeno porte, encerrando um ciclo granodecrescente ou, por vezes, marcando o início de um pulso granocrescente ascendente. Esse fato se deve à: (i) taxa de sedimentação rápida (episódica) situada nas porções médias de leques aluviais (Blair \& McPherson 1994), imediatamente abaixo do ponto de intersecção do leque, onde o desconfinamento simultâneo de canais dos fluxos aquosos torrenciais associados à rápida deposição impediria o desenvolvimento mais significativo de superfícies de corte, refletindo processo de enchentes em lençol; (ii) tabularidade das camadas indica condições de deposição a partir de fluxos subaquosos desconfinados, o que favorece uma vinculação com depósitos de enchentes em lençol. A falta de intercalações pelíticas mais pronunciadas e evidências de retrabalhamento por correntes sob regime de fluxo inferior (trativas) de alta energia (fácies $\mathrm{Ct}$ e Acg) sugerem a existência de condições deposicionais subaéreas. A estruturação interna das fácies Ce coaduna com as feições características de depósitos de fluxos aquosos de leques aluviais (depósitos de sheet flood e stream channel), tal como discutidas em Steel et al. (1977), Nilsen (1982), Blair \& McPherson (1994) e Blair (1999), a seguir enunciadas: (i) deposição relativamente próxima à área fonte; (ii) maior organização dos depósitos com referência àqueles mais proximais, embora preservando a imaturidade textural e mineralógica dos depósitos; (iii) depósitos canalizados e com estratificação cruzada acanalada e tabulares de pequeno e médio portes; (iv) granodecrescência ascendente e (v) imbricação dos clastos.

Depósitos de sistema fluvial entrelaçado Esta sucessão possui passagem gradacional lateral e verticalmente com a sucessão de leques aluviais e apresenta ocorrência monótona de arenitos com intercalações conglomeráticas. Assim, destacam-se as seguintes fácies: (i) conglomerados estratificados (fácies Ce), (ii) conglomerados com estratificação cruzada tabular de médio e pequeno porte (fácies $\mathrm{Ct}$ ), (iii) arenitos conglomeráticos com estratificação cruzada acanalada de pequeno e médio porte (fácies $\mathrm{Acg}$ ), (iv) arenitos maciços (fácies Am), (v) arenitos grossos a médios com estratificação cruzada acanalada de médio e pequeno porte (fácies Aa), (vi) arenitos médios a finos com estratificação plano-paralela (fácies Ap), (vii) arenitos com estratificação cruzada tabular (fácies At) e (viii) arenitos com estruturas de fluidificação (Af) (Fig. 12).

Os conglomerados estratificados (fácies Ce) são polimíticos, organizados (estratificados), de geometria predominantemente lenticular, sustentados por arcabouço constituído de clastos em geral arredondados e de esfericidade média a alta, granulometria seixo pequeno a matacão ( $\phi_{\text {máx. }}=49 \mathrm{~cm}$, pegmatito). A estratificação plano-paralela da rocha é denotada pela gradação normal e orientação dos clastos, sendo esta melhor observada nos termos discóides e alongados. Compõem camadas de espessura variada desde métricas (1-3 m) a decimétricas (10-15 cm).

Os conglomerados da fácies Ct são polimíticos, organizados, com estratificação cruzada tabular de médio e pequeno porte, lentes arenosas intercaladas e feições métricas de corte e preenchimento. Geralmente mostram-se sustentados por matriz de arenito arcoseano mal selecionado (arcabouço $<50 \%$ ), mas com ocorrência de bolsões métricos de conglomerados sustentados por arcabouço, com freqüente imbricação de clastos. Estes possuem dimensões entre 2 e $12 \mathrm{~cm}$, com tamanho máximo de $18 \mathrm{~cm}$, e são subangulosos a arredondados.

Os arenitos grossos a médios da fácies Acg são conglomeráticos, organizados (estratificados), com seixos (predominantemente) e calhaus (esporadicamente) e apresentam coloração 

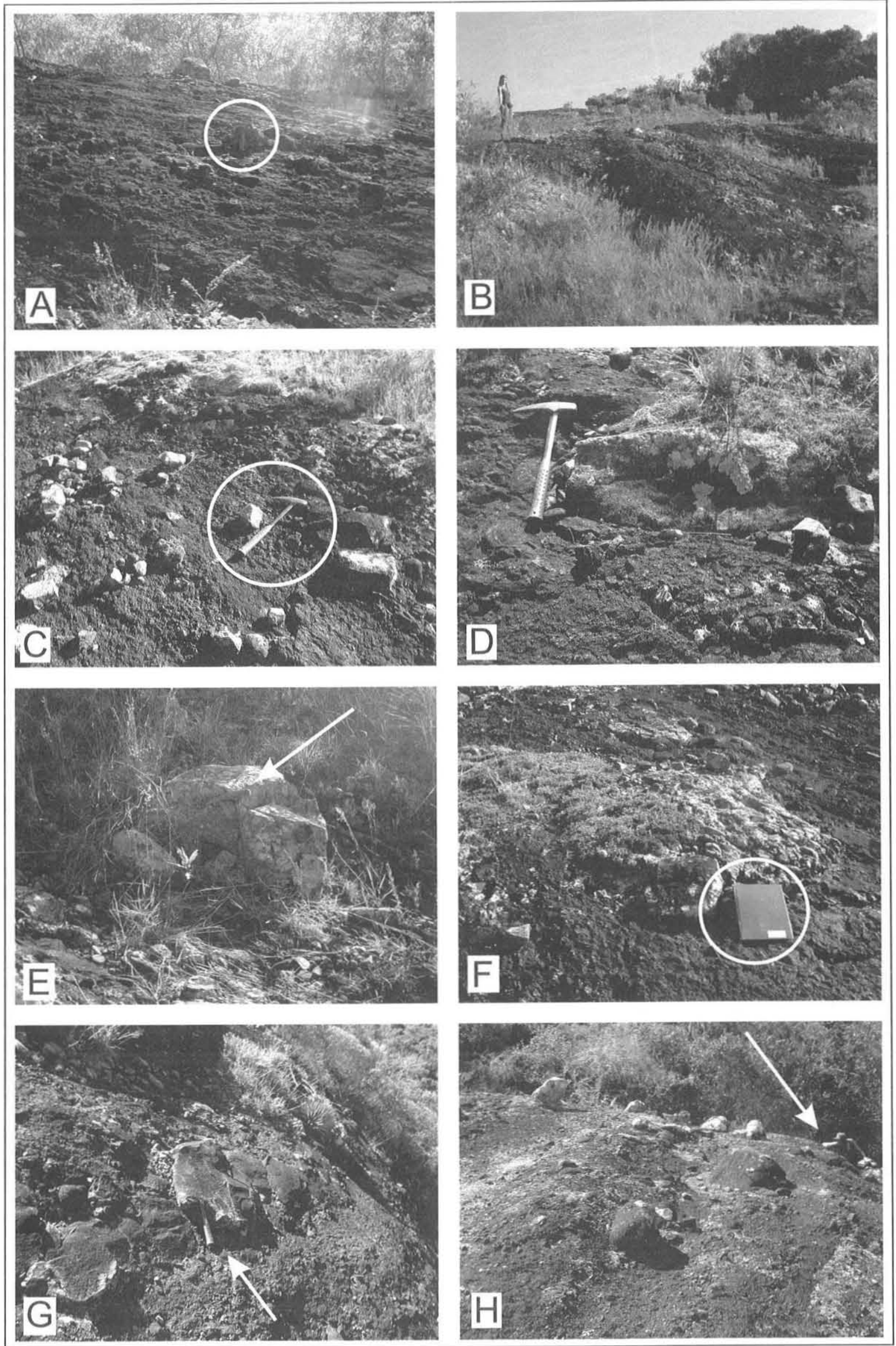

Figura 08 - Conglomerados de leque subaquoso da Associação Intermediária da Formação Passo da Capela no Vale do Piquiri. A e B: conglomerados estratificados tabulares (fácies Ce), C e D: calhaus e matacões angulosos a subangulosos de arenitos nos conglomerados maciços (fácies Cma), E: detalhe de matacão de quartzito, F: concentração de clastos nos conglomerados estratificados (principalmente arenitos). G: megaclastos de arenitos que constituem uma camada de mais de 8 m de comprimento, H: conglomerados estratificados com diversos clastos de arenitos. Círculos e setas indicam escala. 


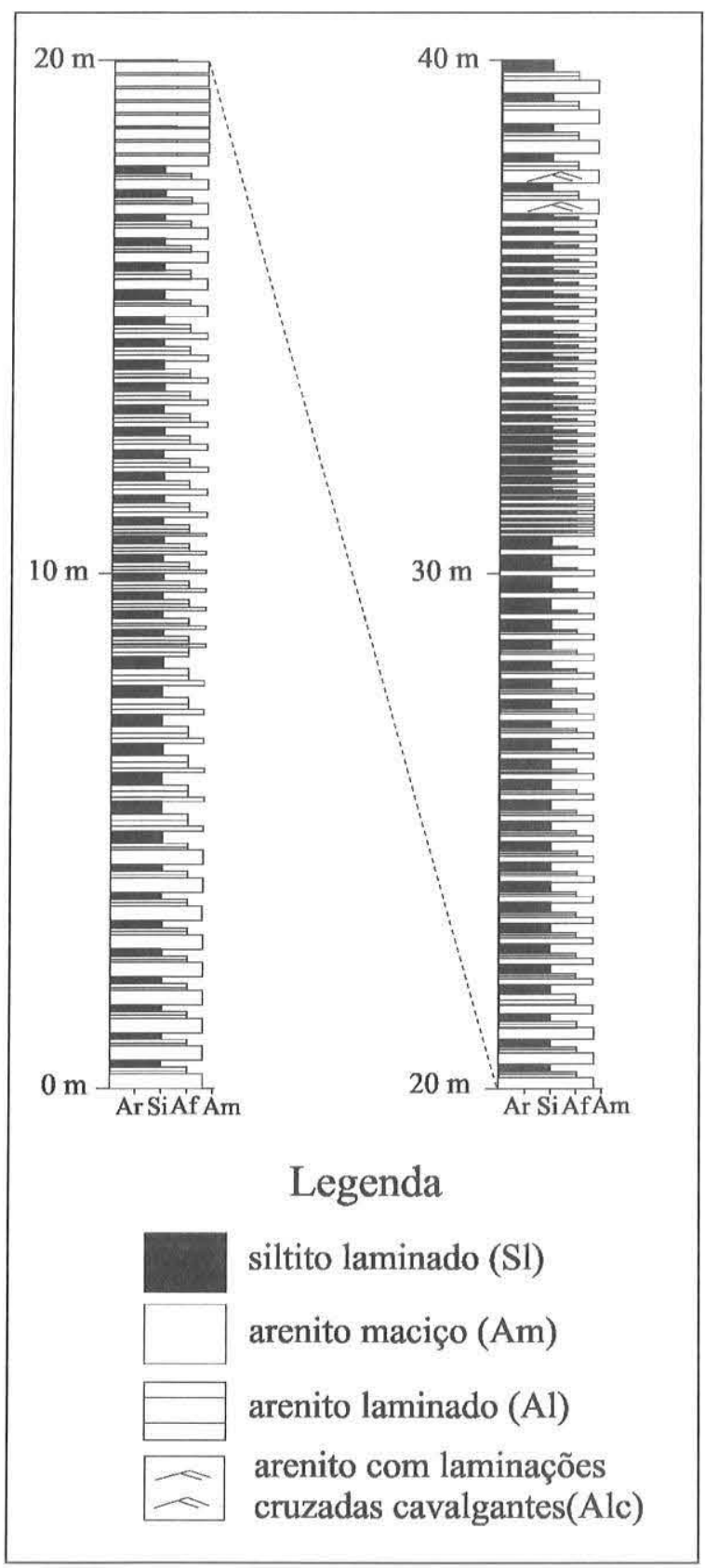

Figura 09 - Seção de detalhe dos turbiditos da Associação Superior da Formação Passo da Capela no Vale do Piquiri.

róseo-avermelhada a creme (Fig. 12). A matriz é constituída por arenito grosso a médio, por vezes com grânulos, mal selecionada, com grãos angulosos a subarredondados. Estes arenitos conglomeráticos apresentam abundantes estratos com estratificação cruzada acanalada de pequeno e médio porte, com clastos dispondo-se nos estratos frontais das mesmas (foresets). Lateralmente, passam para arenitos médios maciços (fácies Am) a bem estratificados (fácies Ap), com seixos esparsos, com estratificação plano-paralela conspícua. Para o topo, aumentam a espessura das camadas e a granulometria dos clastos, além de maior abundância de fragmentos de composição granítica.

Entretanto, a principal fácies destes depósitos são os arenitos grossos a médios com estratificação cruzada acanalada de médio e pequeno porte (fácies $\mathrm{Aa}$ ), com clastos dispondo-se nos estratos frontais das mesmas, realçando-as. Ocorrem bolsões de concentração de clastos na base das camadas. Os pacotes são decimétricos a métricos ( $70 \mathrm{~cm}$ a $1,5 \mathrm{~m}$ de espessura).
A fácies de arenitos com estruturas de fluidificação (Af), de ocorrência restrita, compõe-se de arenitos muito mal selecionados, maciços ou com estruturas reliquiares convolucionadas, freqüentemente com proporções variáveis de silte e/ou argila dispersos na matriz, além de micas e raros grânulos. Devido à presença ocasional de laminação contorcida, preservada em meio à massa mal selecionada, e de camadas pelíticas interrompidas e complexamente dobradas, interpreta-se esta fácies provavelmente como resultado de perturbação de depósitos arenosos e siltosos por processos de perda de fluidos e/ou fluidificação por sobrecarga, apesar da sismicidade identificada na bacia.

As características apontadas acima permitem, de acordo com os trabalhos sobre sistemas fluviais de Rust (1972), Cant \& Walker (1978), Blair \& McPherson (1994) e de Miall (1977, 1981, 1996), considerar esses depósitos como originados por rios entrelaçados arenosos distais (distal braided), com processos de enchentes em lençol, devido à presença de fluxo desconfinado, interpretação corroborada pela ausência tanto de grandes canais como de planícies de inundação.

\section{SEQÜÊNCIAS DEPOSICIONAIS}

Seqüência 1 A seqüência inferior preservada na Sub-Bacia Camaquã Oriental, denominada Seqüência 1, é limitada na base por uma discordância litológica (não-conformidade) com o embasamento ígneo-metamórfico. A Seqüência 1 destaca-se pela presença de espessa sucessão retrogradacional (até $1500 \mathrm{~m}$ de espessura) constituída por brechas e conglomerados sustentados por arcabouço e arenitos e siltitos granodecrescentes. Esta seqüência principia com conglomerados e brechas de leques subaquáticos (até $200 \mathrm{~m}$ de espessura) que transicionam lateral e verticalmente para arenitos finos e siltitos intercalados ritmicamente. Os depósitos rudáceos representariam trato de sistemas de mar baixo. Essa passagem gradacional, porém brusca, para ritmitos finos foi interpretada como uma superfície transgressiva sobre o trato de mar alto. A extremidade superior da Seqüência 1 com a Seqüência 2 é feita através de discordância erosiva de conglomerados grossos de leques subaquosos proximais em contato brusco com turbiditos distais (arenitos finos e siltitos). A primeira seqüência é, portanto, caracterizada pela elevada espessura do trato transgressivo $(\sim 1500 \mathrm{~m})$ e pela pouca espessura do trato de mar alto.

Seqüência 2 A Seqüência 2 acha-se limitada com a Seqüência 1 por discordância erosiva, na situação ideal, assinalada pela presença de possantes conglomerados subaquosos "proximais" sobre ritmitos de (i) turbiditos finos mediano-distais, ou (ii) tempestitos de costa-afora ou (iii) tempestitos de face litorânea. Tal discordância erosiva representa a primeira superfície importante da sucessão da Sub-Bacia Camaquã Oriental. Esta superfície clara (limite de seqüências) separa, em grande parte da sucessão, turbiditos finos mediano-distais de depósitos de turbiditos de alta densidade (conglomerados nas porções proximais e turbiditos espessos nas distais). A superfície pode ser erosiva se ocorrer na base de um rudito de canal subaquoso (região proximal do leque a sul do vale), ou então planar se na base de uma sucessão de arenitos de lobo (sheet sandstones). ’̀ medida que se dirige corrente abaixo, a expressão perfeita do limite de seqüência (superfície) modifica-se, com tendência geral mais erosiva e brusca a montante, e gradacional a brusca em áreas a juzante. A superfície limitante da Seqüência 2 pode ser seguida por grande distância, tanto no campo como em produtos de sensoriamento remoto.

Seqüência 3 Na Sub-Bacia Camaquã Oriental esta seqüência possui as melhores e mais amplas exposições registradas até o momento. A Seqüência 3 apresenta padrão granodecrescente de 


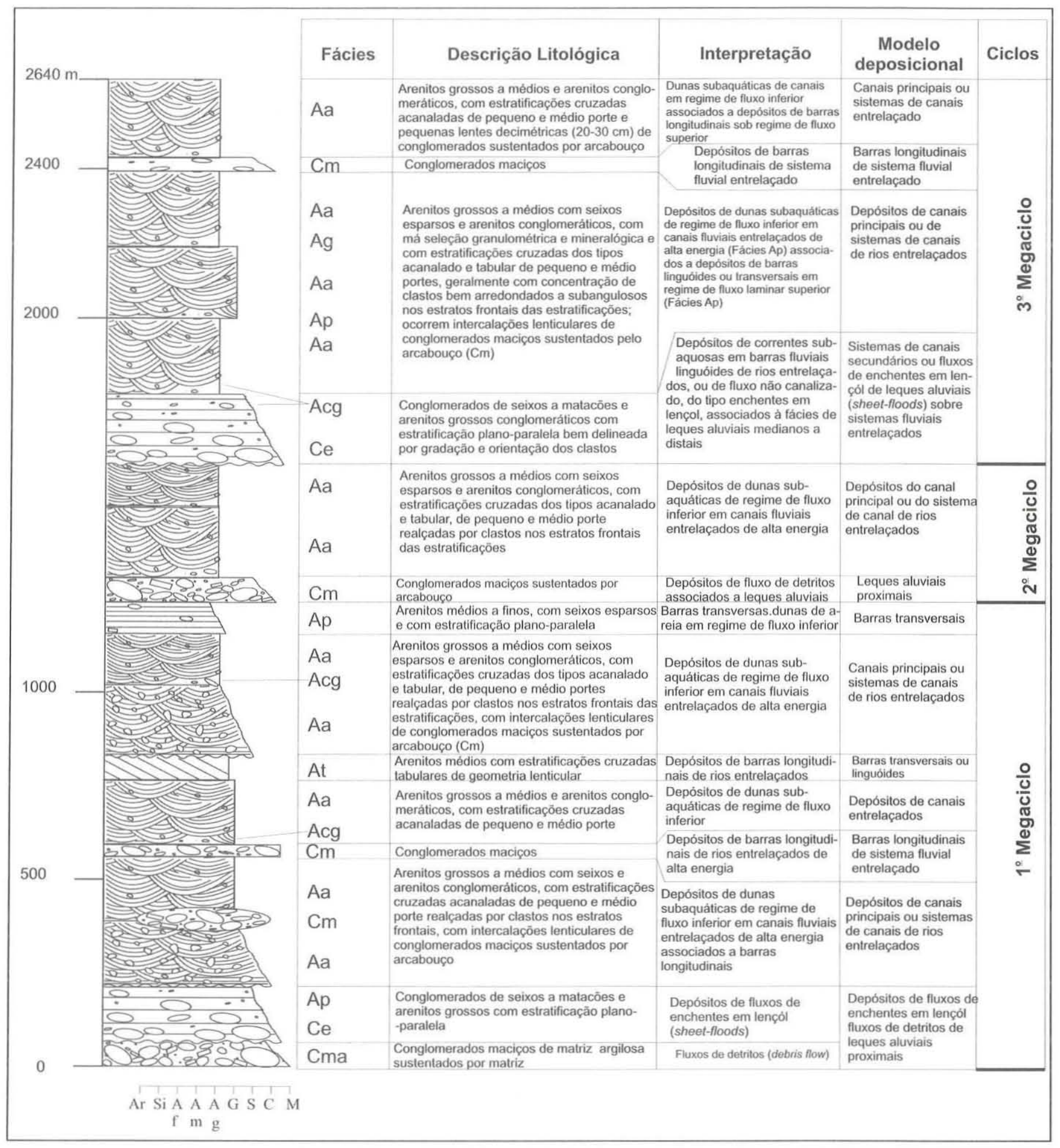

Figura 10 - Seção colunar geral da Formação Rincão dos Mouras na região homônima. Observar três megaciclos. Modelos deposicionais com base nos trabalhos de Miall (1977, 1981, 1996).

conglomerados organizados a desorganizados, arenitos conglomeráticos com seixos e alguns calhaus e de arenitos com seixos esparsos, ambos estratificados. A sucessão é interpretada como depósitos de leques aluviais proximais a distais dominados por enchente em lençol que passam para depósitos fluviais de rios entrelaçados de alta energia. Esta seqüência assenta-se por discordância erosiva e angular sobre a Seqüência 2.

SÍNTESE DA EVOLUÇÃO DA SUB-BACIA CAMAQUÃ ORIENTAL O empilhamento estratigráfico da Sub-Bacia
Camaquã Oriental permite a caracterização de ciclos progradacionais-retrogradacionais. Estes ciclos foram interpretados como resultado de variações relativas do nível de base, possivelmente relacionadas em alguma medida a variações relativas do nível do mar, associadas a mudanças no equilíbrio entre subsidência e aporte sedimentar, ambos relacionados à evolução tectônica da Bacia do Camaquã. Este quadro em conjunto possibilita a elaboração de um modelo paleogeográfico para a região.

A deposição do Grupo Santa Bárbara foi controlada pelas estruturas antigas do embasamento que geraram um amplo sis- 

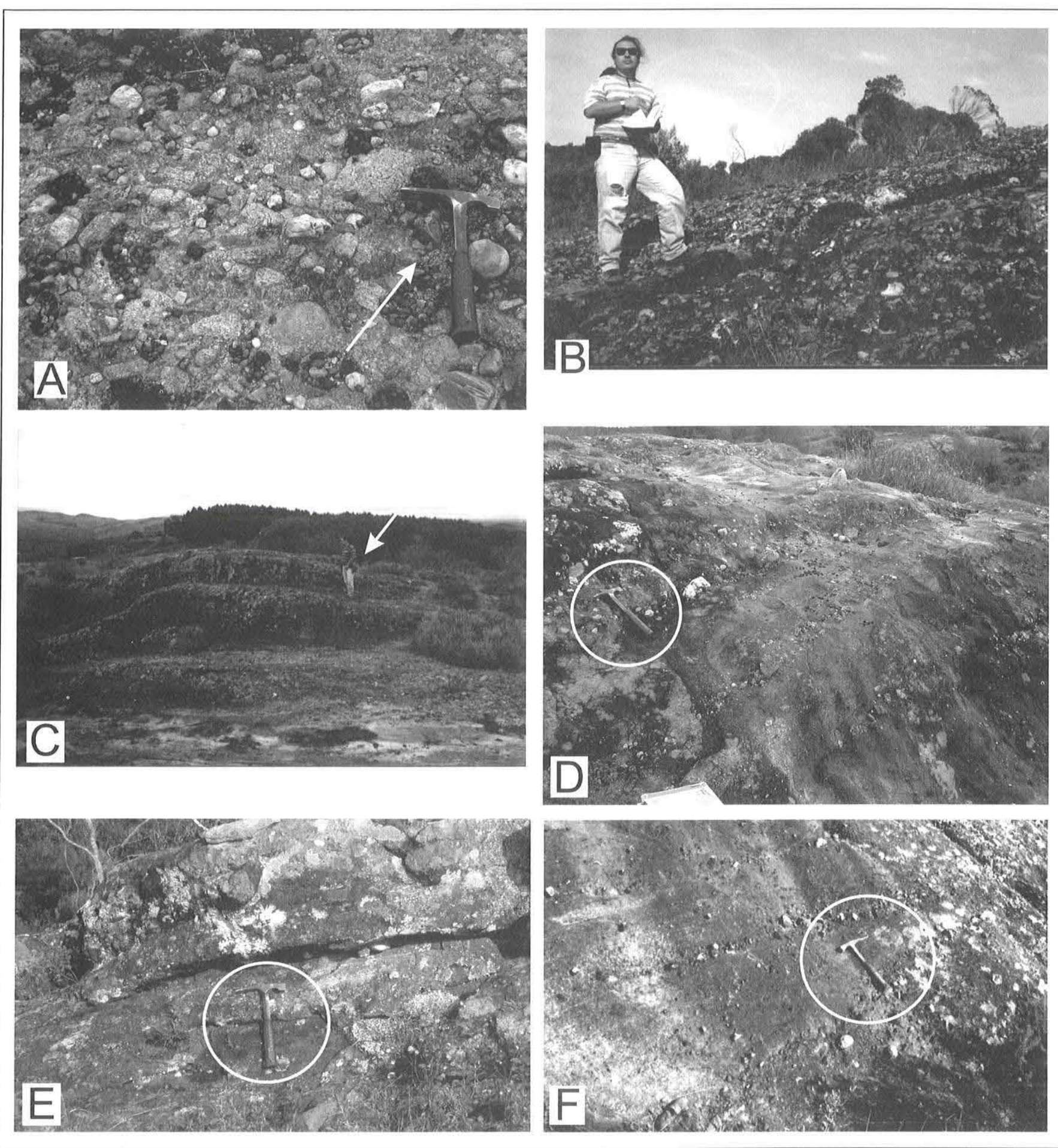

Figura 11 - Fácies de conglomerados e arenitos de leques aluviais da Formação Rincão dos Mouras na região homônima. A: conglomerados maciços Cm, B: conglomerados estratificados Ce, C: conglomerados estratificados Ce, D: conglomerados lenticulares e arenitos conglomeráticos Acg, E: conglomerados estratificados Ce e arenitos conglomeráticos Acg, F: arenitos conglomeráticos com estratificação cruzada acanalada Acg. Círculos e setas indicam escala.

tema de hemi-grábens com sistema de falhas mestras instaladas na borda leste da bacia. Nesta borda, durante a fase de preenchimento inicial da sub-bacia ocorrem depósitos marinhos de leque subaquoso da Formação Passo da Capela. Nesta fase de evolução paleogeográfica do Grupo Santa Bárbara predominaram sistemas provavelmente marinhos de águas rasas e pouco mais profundas cujo depocentro se situava a norte, compreendendo amplo mar de características epicontinentais. Esse corpo marinho é representado pelos depósitos de leques subaquosos e tur- biditos, além de depósitos de tempestitos. A presença de depósitos de leques subaquosos e turbiditos a sul indica a presença de cânions ou canais das porções proximais a medianas de leques subaquosos que serviram de transporte de fluxos sedimentares densos, os quais foram movimentados para as porções mais distais do leque por correntes de turbidez de baixa densidade.

Após o desenvolvimento dos sistemas costeiros e de leques subaquosos da Formação Passo da Capela, a reativação das falhas de borda da bacia propiciou o gigantesco aporte de sedi- 

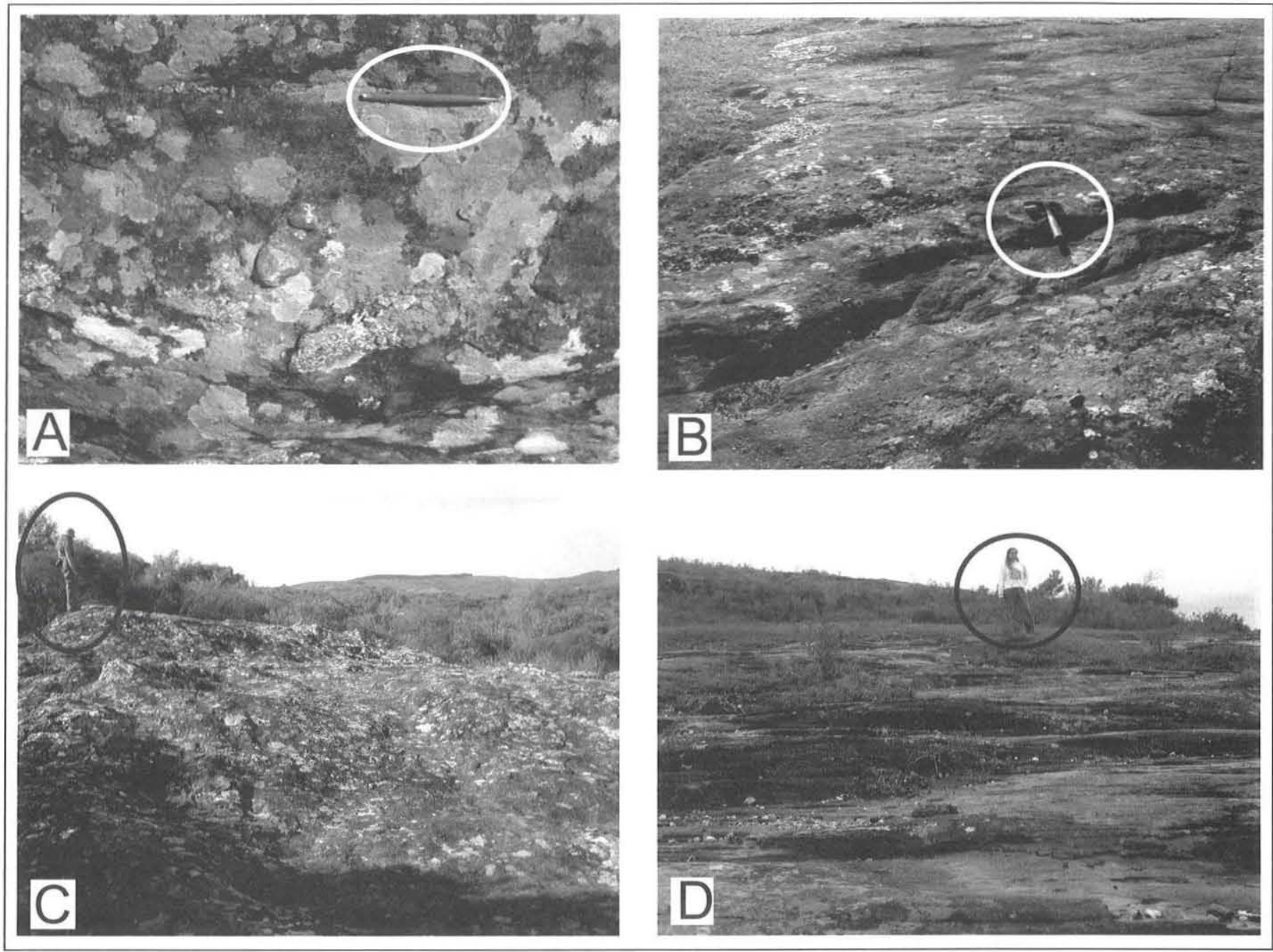

Figura 12 - Fácies de arenitos fluviais da Formação Rincão dos Mouras na região homônima. A: arenitos conglomeráticos com clastos Acg, B: arenitos com estratificação cruzada acanalada Aa, C: arenitos maciços, D: arenitos com estratificação plano-paralela Ap. Círculos indicam escala.

mentos que supriu a Formação Rincão dos Mouras (Seqüência 3). Esta seqüência, composta de arenitos e conglomerados aluviais, marca a inversão da Sub-Bacia Camaquã Oriental, tanto no Vale do Piquiri/Rincão dos Mouras como no Arroio Boici (Sayeg et al. 1992), com a instalação de altos que individualizaram a bacia e resultaram em configuração próxima da atual. A seqüência 3 reflete ciclo de geração de espaço de acomodação de preenchimento da bacia, interpretado como conseqüência direta do estabelecimento dos altos que limitaram a sub-bacia. Após a ingressão marinha inicial (seqüências 1 e 2), decorrente da reativação das falhas a leste da sub-bacia, a presença de áreas elevadas e de escarpa abrupta no relevo geraram aumento tanto do volume de aporte sedimentar local quanto da granulometria desse sedimento, inibindo o escoamento dos detritos para regiões distais (bypassing). Assim, apesar de haver certo lapso de tempo entre a instalação da atividade tectônica e a atuação máxima dos processos de denudação do alto, espessos depósitos, inicialmente de leques aluviais proximais e, finalmente, fluviais, instalaram-se sobre o pacote retrogradacional em um padrão de preenchimento análogo àquele gerado pela passagem de tratos transgressivos para tratos de mar alto em ciclos eustáticos. A seqüência 3 possui uma evolução fortemente influenciada pela atividade tectônica nas falhas de borda, evidenciada por depósitos de leques aluviais proximais que transicionam para sistemas fluviais entrelaçados arenosos de alta energia em toda a suces- são, sendo assim análoga ao trato de mar alto.

CONSIDERAC ÕES FINAIS O Grupo Santa Bárbara na SubBacia Camaquã Oriental na região do Vale do Piquiri reflete os episódios de processos de tectônica, subsidência e aporte de sedimentos. Somente esta unidade foi registrada nesta sub-bacia.

O Grupo Santa Bárbara compõe-se de uma espessa sucessão siliciclástica $(>6000 \mathrm{~m})$ posterior às atividades vulcânicas, com predomínio de conglomerados e arenitos grossos de ambientes aluviais e de leque subaquoso, arenitos e ritmitos costeiros e marinho rasos sob ação de marés e ondas, e uma espessa sucessão depositada abaixo da ação de ondas de tempestade. Desta forma, esta unidade apresenta uma sedimentação aluvial-marinhaaluvial principal, típica de sistemas de riftes intracontinentais.

O soerguimento destes altos internos propiciou a instalação de sistemas de leques aluviais e de planícies fluviais que caracterizam as sucessões basais desta seqüência. A integração dos dados obtidos aponta que o Grupo Santa Bárbara e, por extensão todo o Supergrupo Camaquã, depositou-se em uma bacia extensional tipo rifte, com falhas de borda de rejeito normal ou oblíquo, sem grandes rejeitos direcionais, cujo preenchimento sedimentar foi controlado, sobretudo, pelos seguintes fatores: subsidência tectônica, aporte sedimentar e padrões de transporte sedimentar- sob influência das variações relativas do nivel do mar. 
Agradecimentos Este trabalho é parte da Tese de Doutoramento de G.L.Fambrini, que é grato aos Profs. Drs. Clayton M. S. Scherer (UFRGS), Mário L. Assine (IGCE/UNESP), Paulo Cesar F. Giannini e Cláudio Riccomini (IGc-USP) pelas sugestões proporcionadas durante a defesa. Os autores agradecem à FAPESP pelo suporte financeiro (Processos 98/04510-1 e $00 / 07510-4)$ e pela bolsa concedida à G.L.Fambrini $(98 / 03682-$ 3). Aos colegas Dra. Ana Paula M. R. Pelosi (PETROBRÁS) e Prof. Dr. Afonso C. R. Nogueira (UFPA) pela colaboração nos trabalhos de campo e pelas discussões e sugestões apresentadas. Aos estagiários Ana Paula Justo e Arthur J. C. Silva do PIBIC/
CNPq pelo auxílio nos trabalhos de campo. O empréstimo de fotografias aéreas e de alguns mapas foi facilitado pelos geólogos Ricardo C. Lopes, Wilson Wildner e Eduardo Camozzato (SUREG-PA/CPRM), aos quais somos gratos. Marlei A. C. Chamani digitalizou o mapa geológico, a quem agradecemos. Ao geólogo Gerson Caravaca (PETROBRÁS) somos gratos pela gentileza do empréstimo de sua Dissertação de Mestrado. Agradecemos os revisores da RBG Profs. Drs. Setembrino Petri (IGc-USP) e Marcelo A. Martins Neto (UFOP), pelas inestimáveis sugestões que aprimoraram o manuscrito original, e aos editores, pela pronta editoração do artigo.

\section{Referências}

Almeida F.F.M. 1969. Diferenciação tectônica da Plataforma Brasileira. In: SBG, Cong. Bras. Geol., 23, Salvador, BA, Anais, v.1, p. 29-46.

Almeida R.P. 2001. Evolução Tectono-sedimentar da Formação Santa Bárbara na Sub-Bacia Camaquã Ocidental. Dissertação de Mestrado, Instituto de Geociências, Universidade de São Paulo, 161 p.

Blair T.C. 1999. Cause of dominance by sheetflood vs. debris-flow processes on two adjoining alluvial fans, Death Valley, California. Sedimentology, 46(6): 1015-1028.

Blair T.C. \& McPherson J.G. 1994. Alluvial fans and their natural distinction from rivers based on morphology, hidraulic processes, sedimentary processes and facies assemblages. J. Sed. Petrol., Section A, 64(3):450-489.

Blissenbach E. 1954. Geology of alluvial fans in semi-arid regions. Geol. Soc. Am. Bull., 65(2):175-190.

Bluck B.J. 1964. Sedimentation of an alluvial fan in southern Nevada. J. Sed. Petrol., 34:395-400.

Bull W.B. 1964. Alluvial fans and near-surface subsidence in Western Fresno County, California. U.S.G.S. Professional Paper 437A, 70 p.

Bull W.B. 1972. Recognition of alluvial-fan deposit in the stratigraphic record. In: J K. Rigby \& W.K. Hamblin (eds.) Recognition of Ancient Sedimentary Environments. Tulsa, Soc. Econ. Paleont. Miner. (Special Publication 16), p. 63-83.

Cant D.J. \& Walker R.G. 1978. Fluvial process and facies sequences in the sandy braided South Saskatchewan River, Canada. Sedimentology, 25(5):625-648.

Caravaca G. 1998. Estratigrafia, faciologia e proveniência dos alogrupos Bom Jardim e Santa Bárbara na região de Encruzilhada do Sul, RS: uma contribuição à análise da Bacia do Camaquã. Dissertação de Mestrado, Universidade Federal do Rio Grande do Sul, Porto Alegre, $274 \mathrm{p}$.

Caravaca G., Fernandes L.A.D., Scherer C.M.S. 2001. Estratigrafia e mecanismos controladores da sedimentação da Bacia Piquiri (Proterozóico Superior), porção oriental do Escudo Sul-Riograndense, Brasil. In: Cong. Latinoamericano Geología, 11 / Cong. Uruguayo Geología, 3, Montevideo, 2001 (CDRom).

Collinson J.D. \& Thompson D.B. 1989. Sedimentary structures. London, Unwin Hyman, 207 p.

Fambrini G.L. 2003. O Grupo Santa Bárbara (Neoproterozóico III) a norte do rio Camaquã, Rio Grande do Sul, Brasil. Tese de Doutoramento, Instituto de Geociências, Universidade de São Paulo, 243 p.

Fambrini G.L., Fragoso-Cesar A.R.S., Riccomini C., Janikian L., Almeida R.P., Pelosi A.P.M.R. 2001. Tectônica extensional sin-deposicional na Formação Santa Bárbara, Bacia do Camaquã, RS (Neoproterozóico III-Cambriano Inferior). In: SBG/ABGP, Simp. Nac. Estudos Tectônicos, 8, Recife, Anais, p. 149-150.

Fambrini G.L., Janikian L., Almeida R.P., Fragoso-Cesar A.R.S. 2005. O Grupo Santa Bárbara (Ediacarano) na Sub-Bacia Camaquã Central, RS: estratigrafia e sistemas deposicionais. Rev. Bras. Geoc., 35(2):227-238

Fambrini G.L., Saes G.S., Fragoso-Cesar A.R.S., Silva Filho W.F., Sayeg H.S., Teixeira G., Machado R., McReath I., Ribeiro de Almeida T.I., Phillip R.P. 1996. Sistemas costeiros da Formação Santa Bárbara, Bacia do Camaquã, RS (transição Proterozóico-Fanerozóico): registro preliminar da sedimentação em ambiente de águas rasas domi- nado por ondas. In: SBG, Cong. Bras. Geol., 39, Salvador, BA, Bol. Res. Exp.,v. 2, p. 204-206.

Fragoso-Cesar A.R.S. 1984. Evolução paleoambiental e tectônica da Bacia do Camaquã: uma introdução. Dissertação de Mestrado, Universidade Federal do Rio Grande do Sul, Porto Alegre, 103 p.

Fragoso-Cesar A.R.S. 1991. Tectônica de Placas no Cíclo Brasiliano: as orogenias dos Cinturões Dom Feliciano e Ribeira no Rio Grande do Sul. Tese de Doutoramento Instituto de Geociências, Universidade de São Paulo, São Paulo, 366 p.

Fragoso-Cesar A.R.S., Wernick E., Soliani Jr. E. 1982. Evolução geotectônica do Cinturão Dom Feliciano - Uma contribuição através da aplicação do modelo da Tectônica de Placas. In: SBG, Cong. Bras. Geol., 32, Salvador, BA, Anais. v. 1, p.13-23.

Fragoso-Cesar A.R.S., Almeida R.P., Fambrini G.L., Pelosi A.P.M.R., Janikian L. 2003. A Bacia Camaquã: um sistema intracontinental anorogênico de rifts do Neoproterozóico III-Eopaleozóico no Rio Grande do Sul. In: SBG, Encontro Estrat. Rio Grande do Sul - Escudos e Bacias, 1, Porto Alegre, RS, Anais, p. 139-144.

Fragoso-Cesar A.R.S., Lavina E.L., Paim P.S.G., Faccini U.F. 1984. A antefossa molássica do Cinturão Dom Feliciano no Escudo do Rio Grande do Sul. In: SBG, Cong. Bras. Geol., 33, Rio de Janeiro, RJ, Anais, v. 7, p. 3272-3283.

Fragoso-Cesar, A.R.S., Almeida, R.P., Pelosi, A.P.M.R., Janikian, L., Fambrini, G.L. 2002. Grupo Camaquã (Neoproterozóico III-Eopaleozóico): a cobertura anorogênica do Escudo Gaúcho no Rio Grande do Sul. In: SBG, Cong. Bras. Geol., 41, João Pessoa, PB. Anais, p. 307.

Fragoso-Cesar A.R.S., Fambrini G.L., Riccomini C., Janikian L., Almeida R.P., Pelosi A.P.M.R., Machado R. 2001. Estruturas induzidas por abalos sísmicos na Seqüência Santa Bárbara (Neoproterozóico III-Eocambriano), Bacia do Camaquã, RS: o exemplo do Passo da Capela.Rev. Bras. Geoc., 31(2):155-162.

Fragoso-Cesar A.R.S., Fambrini G.L., Almeida R.P., Pelosi A.P.M.R., Janikian L., Riccomini C., Machado R., Nogueira A.C.R., Saes G.S. 2000. The Camaquã extensional basin: Neoproterozoic to early Cambrian sequences in southernmost Brazil. Rev. Bras. Geoc., 30(3):438-441.

Gloppen T.G. \& Steel R.J. 1981. The deposits, internal structure and geometry in six alluvial fan-fan delta bodies (Devonian-Norway) - a study in the significance of bedding sequence in conglomerates. In: F.G. Ethridge \& R.M. Flores (eds.) Recent and Ancient Depositional Environments: models for exploration. Tulsa, Soc. Econ. Paleont. Miner, Special Publication 39, p. 49-69.

Gresse P.G., Chemale Jr., F, Silva L.C., Walraven F., Hartmann L.A. 1996. Late- to post-orogenic basins of the Pan-African-Brasiliano collision orogen in southern Africa and southern Brazil. Basin Res., $8(2): 157-171$.

Hempton M.R. \& Dewey J.F. 1983. Earthquake-induced deformation structures in young lacustrine sediments, East Anatolian Fault, southeast Turkey. Tectonophysics, 98:T7-T14.

Hooke R.L. 1967. Processes in arid-region alluvial fans. J. Geol., 75:438460.

Janikian L., Almeida R.P., Fragoso-Cesar A.R.S., Fambrini G.L. 2003. Redefinição do Grupo Bom Jardim (Neoproterozóico III) em sua 
áreatipo: litoestratigrafia, evolução paleoambiental e contexto tectônico. Rev. Bras. Geoc., 33(4):349-362.

Lavina E.L., Faccini U.F., Paim P.S.G., Fragoso Cesar A.R.S. 1985. Ambientes de sedimentação da Bacia do Camaquã, Eo-Paleozóico do Rio Grande do Sul. Acta Geol. Leopold., 21(9):185-227.

Lowe D.R. 1982. Sediment gravity flows: II. Depositional models with special reference to the deposits of high-density turbidity currents. $J$. Sed. Petrol., 52(1):279-297.

Machado R. \& Sayeg H.S. 1992. Aplicação da análise geométrica e cinemática nos falhamentos que condicionaram a bacia molássica do Arroio Boici, RS. In: SBG/UNISINOS, Workshop sobre as bacias molássicas brasilianas, 1, São Leopoldo, RS, Bol. Res. Exp., p. $73-$ 76.

Miall A.D. 1977. A review of the braided-rivers depositional environment. Earth Sci. Rev., 13(1):1-62.

Miall A.D. 1981. Analysis of fluvial depositional systems. AAPG, Special Publication 20, Educational Course Note Series, p. 1-75.

Miall A.D. 1992. Alluvial deposits. In: R.G. Walker \& N.P. James (eds.) Facies models. Response to sea level change. Geol. Assoc. Canada, Waterloo, Ontario, p. 119-142.

Miall A.D. 1996. The geology of fluvial deposits: sedimentary facies, basin analysis and petroleum geology. Springer, $582 \mathrm{p}$.

Middleton G.V. \& Hampton M.A. 1976. Subaqueous sediment transport and deposition by sediment gravity flows. In: D.J. Stanley \& D.J.P. Swift (eds.) Marine sediment transport and environment manegement, John Wiley \& Sons, p. 197-218.

Mills P.C. 1983. Genesis and diagnostic value of soft-sediment deformation structure -a review. Sed. Geol., 35(2):83-104.

Mohindra R. \& Thakur V.C. 1998. Historic large earthquake-induced soft sediment deformation features in the Sub-Himalayan Doon valley. Geol. Mag., 135(2):269-281.

Mutti E. 1992. Turbidite Sandstones. AGIP Special Publication, Milan, 275 pp.

Mutti E., Tinterri R., Remacha E., Mavilla N., Angella S., Fava L. 1999. An introduction to the analysis of ancient turbidite basins from an outcrop perspective. Tulsa, AAPG Continuing Education Course Note Series 39, 61 p.

Nilsen T.H. 1982. Alluvial fans. In: P.A. Scholle \& D. Spearing (eds.) Sandstone Depositional Environments. Tulsa, Am. Assoc. petrol. Geol, Memoir 31, p. 2-84.

Obermeier S.F. 1996. Use of liquefaction-induced features for paleoseismic analysis - an overview of how liquefaction features can be distinguished from other features and how their distribution and properties of source sediment can be used to infer the location and strength of Holocene paleo-earthquakes. Eng. Geol., 44:1-76.

Obermeier S.F., Jacobson R.B., Smoot J.P., Weems R.E., Gohn G.S. Monroe J.E., Powars D.S. 1990. Earthquake-induced liquefaction features in the coastal setting of South Carolina and the fluvial setting of the New Madrid seismic zone. U. S. Geological Survey Professional Paper, 1504, 44p.

Oliveira J.M.M.T. \& Fernandes L.A.D. 1991. Estágios finais da evolução do Cinturão Dom Feliciano: tectônica e sedimentação da Formação Arroio dos Nobres. In: SBG, Simp. Nac. Est. Tectônicos, 3, Rio Claro, SP, Bol. Res. Ext., p. 58-59.
Paim P.S.G., Faccini U.F., Fragoso-Cesar A.R.S., Lavina E.L. 1986. Modelo submarino para a Formação Maricá no Vale do Piquiri (RS): Leques Submarinos X "Debris Apron”. In: SBG, Cong. Bras. Geol., 34, Goiânia, GO, Anais, p. 357-367.

Ribeiro M., Bocchi P. R., Figueiredo Filho P. M., Tessari R.I. 1966. Geologia da Quadrícula de Caçapava do Sul, Rio Grande do Sul. Rio de Janeiro, DNPM/DFPM, Boletim 127, 232 p.

Robertson J.F. 1966. Revision on stratigraphy and nomenclature of rock units in Caçapava-Lavras Region. Notas e Estudos, 1(2):41-54.

Rodríguez-Pascua M.A., Calvo J.P., De Vicente G., Gómez-Gras D. 2000. Soft-sediment deformation structures interpreted as seismites in lacustrine sediments of the Prebetic Zone, SE Spain, and their potential use as indicators of earthquake magnitudes during the Late Miocene. Sed. Geol., 135(1-4):117-135.

Rossetti D.F. 1999. Soft-sediment deformation structures in late Albian to Cenomanian deposits, São Luís Basin, northern Brazil: evidence for palaeoseismicity. Sedimentology, 46(6):1065-1081.

Rossetti D.F. \& Góes A.M. 2000. Deciphering the sedimentological imprint of paleoseismic events: an example from the Aptian Codó Formation, northern Brazil. Sed. Geol., 135(1-4):137-156.

Rust B.R. 1972. Structure and process in a braided river. Sedimentology, 18(2):221-245.

Sayeg H.S., Fambrini G.L., Machado R., Fragoso-Cesar A.R.S. 1992. Evolução brasiliana da bacia transcorrente do Arroio Boici, RS. In: SBG/UNISINOS, Workshop sobre as bacias molássicas brasilianas, 1, São Leopoldo, RS, Bol. Res. Exp., p. 129-132.

Schultz A.W. 1984. Subaerial debris-flow deposition in the Upper Paleozoic Cutler Formation, western Colorado. J. Sed. Petrol., 54(5):759772.

Seilacher A. 1969. Fault-graded beds interpreted as seismites. Sedimentology, 13:155-159.

Sims J.D. 1973. Earthquake-induced structures in sediments of Van Norma Lake, San Fernando, California. Science, 182:161-163.

Steel R.J., Maehle S., Nilsen H., RØe S.L., Spinnangar Å. 1977. Coarsenig-upward cycles in the alluvium of Hornelen Basin (Devonian), Norway: sedimentation response to tectonic events. Geol. Soc. Am. Bull., 88:1124-1134.

Tessari R.I. \& Giffoni L.E. 1970. Geologia da região de Piratini, Pinheiro Machado e Bagé, Rio Grande do Sul. Rio de Janeiro, Boletim da Divisão de Geologia e Mineralogia DNPM 246, 122 p.

Tessari R.I. \& Picada R.S. 1966. Geologia da Quadricula Encruzilhada do Sul, Rio Grande do Sul, Brasil. Rio de Janeiro, DNPM/DFPM, Boletim 124,147 p.

Vittori E., Labini S.S., Serva L. 1991. Palaeoseismology: review of the state-of-the-art. Tectonophysics, 193(1-3):9-32.

Walker R.G. 1992. Facies, facies models and modern stratigraphic concepts. In: R.G. Walker \& N.P. James (eds.) Facies models. Response to sea level change. Geol. Assoc. Canada, Waterloo, Ontario, pp. 1$14 \mathrm{vw}$ 